\title{
Phylogenetic relationships within the speciose family Characidae (Teleostei: Ostariophysi: Characiformes) based on multilocus analysis and extensive ingroup sampling
}

\author{
Claudio Oliveira ${ }^{1 *}$, Gleisy S Avelino ${ }^{1}$, Kelly T Abe ${ }^{1}$, Tatiane C Mariguela ${ }^{1}$, Ricardo C Benine ${ }^{1}$, Guillermo Ortí \\ Richard P Vari ${ }^{3}$ and Ricardo M Corrêa e Castro ${ }^{4}$
}

\begin{abstract}
Background: With nearly 1,100 species, the fish family Characidae represents more than half of the species of Characiformes, and is a key component of Neotropical freshwater ecosystems. The composition, phylogeny, and classification of Characidae is currently uncertain, despite significant efforts based on analysis of morphological and molecular data. No consensus about the monophyly of this group or its position within the order Characiformes has been reached, challenged by the fact that many key studies to date have non-overlapping taxonomic representation and focus only on subsets of this diversity.
\end{abstract}

Results: In the present study we propose a new definition of the family Characidae and a hypothesis of relationships for the Characiformes based on phylogenetic analysis of DNA sequences of two mitochondrial and three nuclear genes (4,680 base pairs). The sequences were obtained from 211 samples representing 166 genera distributed among all 18 recognized families in the order Characiformes, all 14 recognized subfamilies in the Characidae, plus 56 of the genera so far considered incertae sedis in the Characidae. The phylogeny obtained is robust, with most lineages significantly supported by posterior probabilities in Bayesian analysis, and high bootstrap values from maximum likelihood and parsimony analyses.

Conclusion: A monophyletic assemblage strongly supported in all our phylogenetic analysis is herein defined as the Characidae and includes the characiform species lacking a supraorbital bone and with a derived position of the emergence of the hyoid artery from the anterior ceratohyal. To recognize this and several other monophyletic groups within characiforms we propose changes in the limits of several families to facilitate future studies in the Characiformes and particularly the Characidae. This work presents a new phylogenetic framework for a speciose and morphologically diverse group of freshwater fishes of significant ecological and evolutionary importance across the Neotropics and portions of Africa.

\section{Background}

One of the largest components of the freshwater fish fauna world-wide is the order Characiformes with nearly 2,000 species now recognized from myriad drainages of the New World and Africa [1]. Over 300 characiform species have been described in the last decade, primarily from the Neotropics and the pace of descriptions of

\footnotetext{
* Correspondence: claudio@ibb.unesp.br

'Dept. Morfologia, Instituto de Biociências, Universidade Estadual Paulista,

Botucatu, São Paulo, Brazil

Full list of author information is available at the end of the article
}

new species gives no sign of abating. The characiform faunas on the two sides of the Atlantic Ocean demonstrate pronounced asymmetry in terms of numbers of both species and supraspecific taxa. The African components of the order include circa 220 recognized species. These range south from the Nile River basin in the deserts of North Africa through much of the rest of the continent, with maximum diversity in the wetter areas such as the Congo River Basin, West Africa and Lower Guinea. On the other side of the Atlantic Ocean, over 1,700 species are now recognized extending from the 
southwestern portions of the United States south through Mexico and Central and South America to central Chile and Argentina. Major drainage basins in South America are all home to large and taxonomically overlapping assemblages of characiform species. Characiforms inhabit a range of ecosystems extending from the swiftly flowing rivers and streams of the Andean piedmont and cordilleras of the Neotropics through to the lentic backwaters of lowland flood plains in the Americas and Africa. Within these habitats, characiforms range from dozens of miniature and diminutive species (sensu Weitzman and Vari [2]) through to hundreds of midsized to giant species. Among the larger forms, many are economically and ecologically important, with some dominant in various drainages in terms of the total fish biomass. These and other characiform species play key roles for intra-ecosystem energy flux and material cycling in lowland river systems and as ecosystem engineers (e.g. Prochilodontidae - [3,4]).

African characiforms are now apportioned among four families, the Alestidae, Citharinidae, Distichodontidae and Hepsetidae, with the Alestidae and Distichodontidae accounting for $95 \%$ of the species among those families [1]. A single Neotropical genus (Chalceus) has been assigned to the otherwise African family Alestidae [5]. In contrast, the more speciose assemblage of New World characiforms is split into 14 families (Acestrorhynchidae, Anostomidae, Characidae, Chilodontidae, Crenuchidae, Ctenoluciidae, Curimatidae, Cynodontidae, Erythrinidae, Gasteropelecidae, Hemiodontidae, Lebiasinidae, Parodontidae, and Prochilodontidae) [6]; with the
Serrasalmidae also recognized as a family by some authors (e.g. [7]).

To date, a single publication [8] has addressed higher level relationships across major components of the Characiformes based on morphological data. This study used 80 characters and 27 ingroup terminal taxa with representatives from all recognized characiform families except the Cynodontidae, Gasteropelecidae and Serrasalmidae (Figure 1a). Other morphologically based studies, although important, are more taxonomically restricted, focusing on phylogenetic questions ranging from the relationships among a few families through to relationships within families or their components. These included the Alestidae [5], Anostomidae [9,10], Characidae [11-23], Chilodontidae [9,24], Citharinidae [25], Crenuchidae [8], Curimatidae [9,26], Distichodontidae [25], Hemiodontidae [27] and Prochilodontidae $[9,28]$.

Notwithstanding these efforts, no published hypothesis of phylogenetic relationships across characiforms based on an in-depth sampling of their morphological diversity is available. The most problematic group within this order is the family Characidae, whose composition and relationships within the Characiformes remains unsettled. With nearly 1,100 species, this family represents approximately $58 \%$ of the species within the Characiformes [1], and is the most active taxon in terms of new species descriptions (over 250 new species in the course of the last ten years). Considering the poor understanding of species-level diversity, particularly among miniature to small sized species, it is likely that

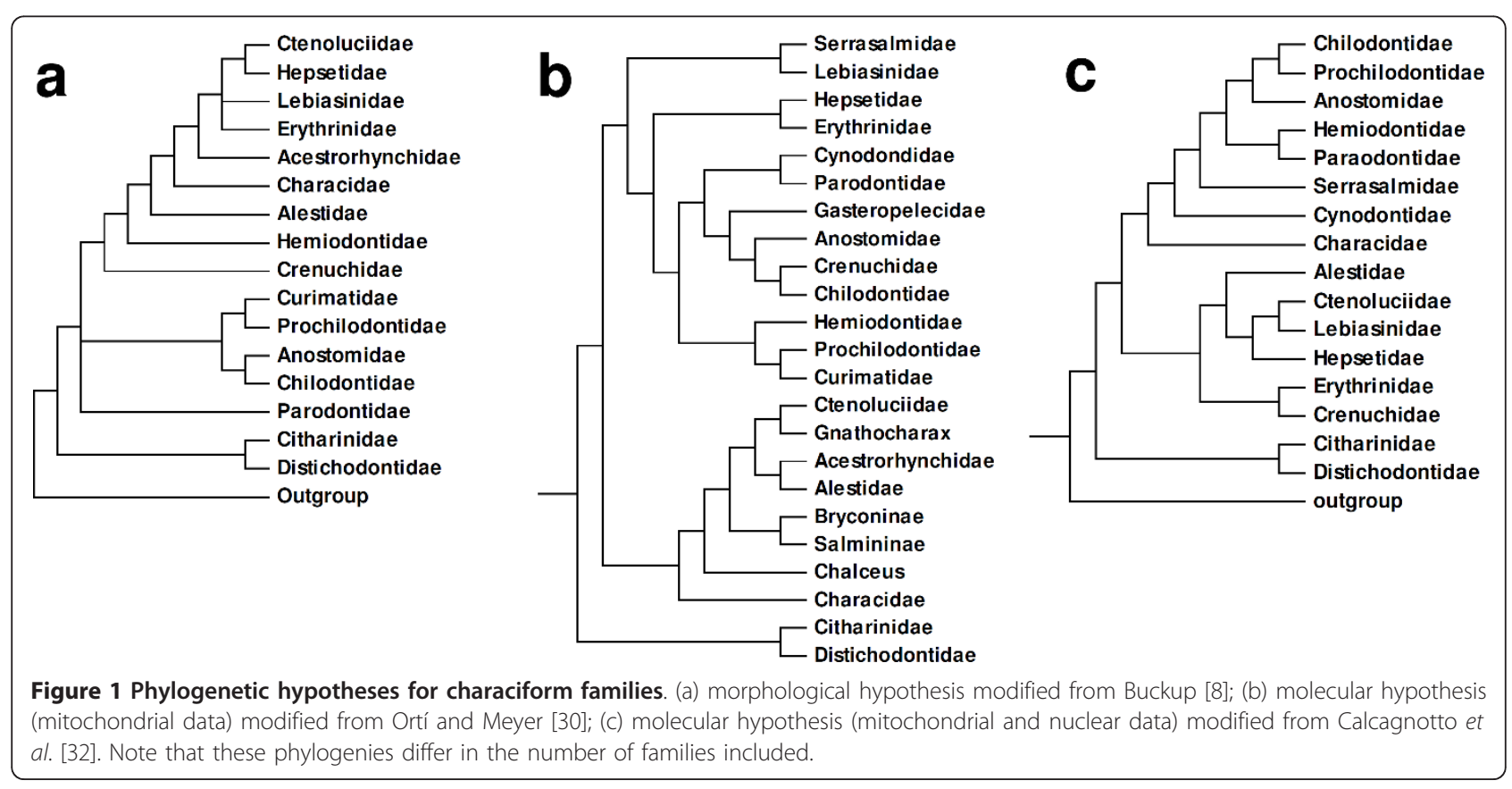


the Characidae includes a disproportionate percentage of species yet to be described.

A classification of the family Characidae proposed by Reis et al. [6] highlighted some of these uncertainties. Twelve of the recognized subfamilies in that classification were assumed to represent monophyletic groups based on published results (Agoniatinae, Aphyocharacinae, Bryconinae, Characinae, Cheirodontinae, Clupeacharacinae, Glandulocaudinae, Iguanodectinae, Rhoadsiinae, Serrasalminae, Stethaprioninae and Tetragonopterinae). Nonetheless, 88 characid genera, many monotypic but others notably speciose (Astyanax, Bryconamericus, Creagrutus, Hemigrammus, Hyphessobrycon, Jupiaba and Moenkhausia), were placed as "incertae sedis in the Characidae" by Lima et al. [29]. Included among these incertae sedis were 620 of the 952 species assigned to the Characidae at that time. Concurrently, Malabarba and Weitzman [19] advanced a cladogram for the group based on four osteological features: (i) the presence of bony hooks on various fins, (ii) the absence of the supraorbital bone, (iii) the possession of two unbranched and eight branched rays in the dorsal fin, and (iv) the presence of four teeth in the inner tooth row of the premaxilla (Figure 2a). Of particular note is that the latter two characters delimited what Malabarba and Weitzman [19] identified as Clade A. This group included many of the genera considered to be incertae sedis in the Characidae by Lima et al. [29] along with taxa previously assigned to the Glandulocaudinae and Stevardiinae.

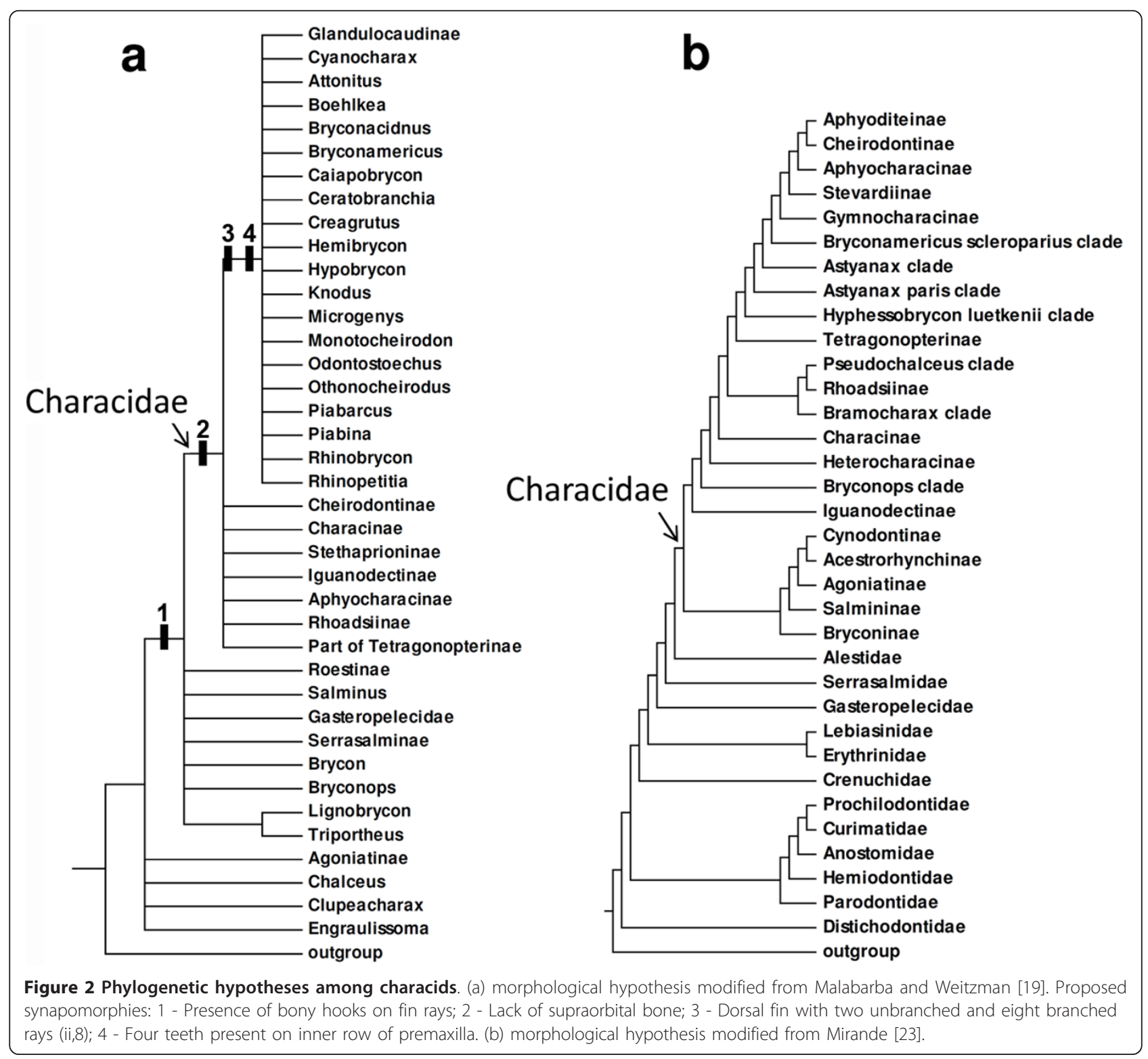


More recently, Mirande [22,23] advanced a comprehensive cladistic analysis for the Characidae based on 360 morphological characters scored for 160 characiform species. Although this study is the most comprehensive to date, it did not include representatives of 60 genera of the Characidae and or representatives from the characiform families Alestidae, Chilodontidae, Citharinidae, Ctenoluciidae and Hepsetidae. Interestingly, Mirande's [23] hypothesis (Figure 2b), obtained by weighted parsimony analysis, recovered the previously proposed Clade A of Malabarba and Weitzman [19] that he named Stevardiinae. On the other hand, Mirande's hypothesis [23] is incongruent with prior concepts of relationships among some taxa, with two examples of note being the close relationship among Agoniates, Acestrorhynchus, Rhaphiodon and Salminus and the inclusion of Markiana within Astyanax.

The first molecular investigations on this subject were published by Ortí and Meyer [30] and Ortí [31]. These were based on partial sequences of the mitochondriallyencoded $12 \mathrm{~S}$ and $16 \mathrm{~S}$ rRNA genes (about $880 \mathrm{bp}$ ) for 53 taxa. Although Ortí and Myer [30] noted that relationships among characiform families could not be reconstructed with confidence except for a few wellsupported clades, their phylogenetic hypothesis (Figure 1b) suggested some interesting results. For example, they obtained a basal position of the African families Citharinidae and Distichodontidae, the hypothesis that the African and Neotropical characiform assemblages did not each constitute monophyletic groups and the finding that the Serrasalmidae is not closely related to groups then considered to form the family Characidae.

Calcagnotto et al. [32] presented a more extensive molecular study of characiforms (Figure 1c) based on sequence analysis of two mitochondrial and four nuclear genes (about $3700 \mathrm{bp}$ ) for 124 characiform taxa (including 59 African representatives but excluding representatives of the Neotropical families Curimatidae and Gasteropelecidae). The large number of African taxa analyzed in that study supported the monophyletic nature of the families Citharinidae, Distichodontidae, Alestidae and Hepsetidae (the latter, however, being monotypic) and again rejected the concept of a monophyletic African assemblage. Five years later, Javonillo et al. [33] advanced a phylogenetic hypothesis for the Characidae (Figure 3) using DNA sequences of three mitochondrial genes and one nuclear gene. They analyzed 2940 bp for 98 taxa, including representatives of eight recognized subfamilies of the Characidae, and 33 genera considered incertae sedis in the Characidae by Lima et al. [29], plus the Acestrorhynchidae (2 species), Gasteropelecidae (3 species), and Serrasalmidae (3 genera). Their hypothesis supported three main clades within the Characidae (clades A, B, and C). Interestingly, all species included in clade A of Javonillo et al. [33] belong to Clade A of Malabarba \& Weitzman [19], thus providing independent support for this hypothesis. Not surprisingly, however, representatives of some speciose

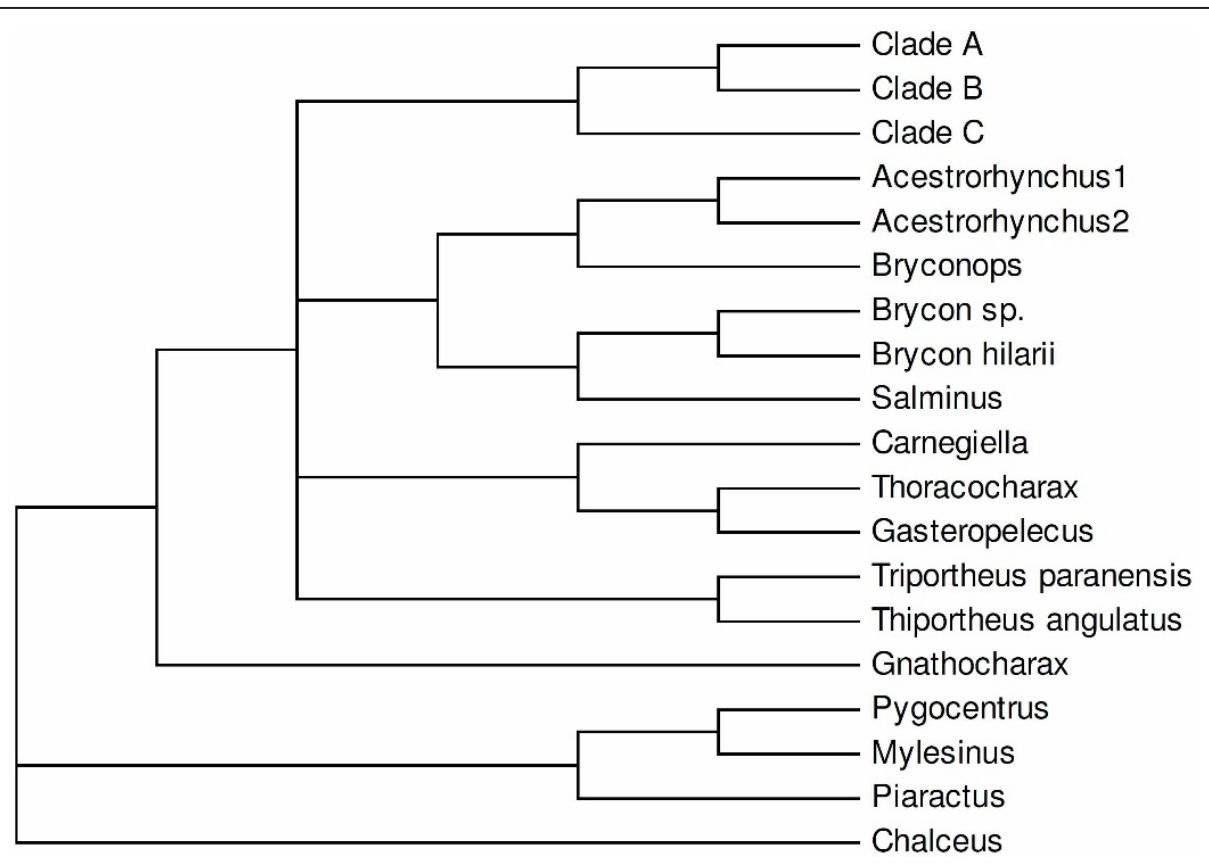

Figure 3 Phylogenetic hypothesis for selected members of the Characidae proposed by Javonillo et al. [33]based on molecular data. Composition and relationships of clades $\mathrm{A}$ to $\mathrm{C}$ are discussed in the text. 
and ill-defined genera such as Astyanax, Bryconamericus, Hemigrammus, and Hyphessobrycon appeared as polyphyletic.

Partial taxonomic overlap and use of disparate molecular markers in each of these studies has hindered combination of data sets for a more comprehensive analysis. Attempting to improve our knowledge and to test previous hypotheses of relationships among members of the Characidae, the present study is based on a broad taxon sampling (including all major lineages within the Characiformes and the Characidae) and a large molecular dataset with sequence data from two mitochondrial and three nuclear genes, with greater overlap with published data.

\section{Methods}

\section{Taxon sampling}

We follow the classification of the Characiformes with 18 families proposed by Nelson [1] as a framework for the selection of species included in this analysis: Acestrorhynchidae, Alestiidae (Alestidae), Anostomidae, Characidae (including the subfamilies Agoniatinae, Aphyocharacinae, Bryconinae, Characinae, Cheirodontinae, Clupeacharacinae, Glandulocaudinae, Iguanodectinae, Rhoadsiinae, Stethaprioninae, Tetragonopterinae), Chilodontidae, Citharinidae, Crenuchidae, Ctenoluciidae, Curimatidae, Cynodontidae, Distichodontidae, Erythrinidae, Gasteropelecidae, Hemiodontidae, Hepsetidae, Lebiasinidae, Parodontidae, and Prochilodontidae. We additionally recognize the family Serrasalmidae and in the Characidae, the subfamilies Stevardiinae as proposed by Weitzman et al. [20] and Triportheinae as proposed by Buckup [34] in selecting taxa for the present study. According to this classification, taxonomic sampling for the ingroup included 127 specimens representing all 13 recognized subfamilies of Characidae listed above, as well as 54 genera considered incertae sedis in the Characidae by Lima et al. [29], plus an undescribed characid genus. To study the delimitation of Characidae and its affinities with other families of Characiformes, we compiled a large and diverse outgroup (76 specimens) representing all 18 families of Characiformes, plus two genera of Cypriniformes to root the Characiform phylogeny. A complete list of taxa (205 specimens) is presented in Additional file 1. Tissue samples were primarily obtained from fish collected during the course of this study, supplemented by material obtained through the aquarium trade, or kindly donated by colleagues.

\section{DNA extraction and sequencing}

Total DNA was extracted from ethanol preserved muscle, fin, and liver samples with the DNeasy Tissue Kit (Qiagen), following manufacturer's instructions. Partial sequences of the genes 16S rRNA, cytochrome $b$ (Cytb),
Myosin, heavy chain 6, cardiac muscle, alpha (Myh6), recombination activating gene 1 (RAG1), and recombination activating gene 2 (RAG2) were amplified by polymerase chain reaction (PCR) with the primers described in Additional file 2. Nested-PCRs were used to amplify the genes Myh6, Rag1, and Rag2 (Additional file 2). Amplifications were performed in a total volume of 25 $\mu \mathrm{l}$ with $2.5 \mu \mathrm{l}$ of $10 \mathrm{X}$ buffer $(10 \mathrm{mM}$ Tris- $\mathrm{HCl}+15 \mathrm{mM}$ $\mathrm{MgCl}_{2}$ ), $2.5 \mu \mathrm{l}$ dNTPs (200 nM of each), $1 \mu \mathrm{l}$ each 5 $\mathrm{mM}$ primer, $0.1 \mu \mathrm{l}$ Taq Gold polymerase (Invitrogen), 1 $\mu$ template DNA (50 ng), and $17.9 \mu \mathrm{ddd}_{2} \mathrm{O}$. The PCR reactions consisted of 35 cycles, $30 \mathrm{~s}$ at $95^{\circ} \mathrm{C}, 45-120 \mathrm{~s}$ at $48-58^{\circ} \mathrm{C}$ (according to primer and species), and $90 \mathrm{~s}$ at $72^{\circ} \mathrm{C}$. All PCR products were first visually identified on a $1 \%$ agarose gel and then purified using ExoSap-IT ${ }^{\circledR}$ (USB Corporation) following instructions of the manufacturer. The purified PCR products were sequenced using the "Big DyeTM Terminator v 3.1 Cycle Sequencing Ready Reaction Kit" (Applied Biosystems), purified again by ethanol precipitation and loaded on an automatic sequencer 3130-Genetic Analyzer (Applied Biosystems) in the Instituto de Biociências, Universidade Estadual Paulista, Botucatu, São Paulo. Contigs were assembled and edited in BioEdit 7.0.9.0 [35]. Where uncertainty of nucleotide identity was detected, IUPAC ambiguity codes were applied. Sequences have been deposited in GenBank (Additional file 3).

\section{Sequencing alignment and phylogenetic analyses}

Sequences of each gene were independently aligned using the Muscle algorithm under default parameters [36] and the alignments inspected by eye for any obvious misalignments that were then corrected. A quality control step was included in our workflow to detect potential cases of sequencing errors due to contamination or paralogy. Alignments for each gene were initially analyzed by maximum likelihood (ML) [37] using the web servers RAxML BlackBox [38] to control for potential sequencing errors involving pseudogenes, paralogous copies or even laboratory cross-contamination or mistakes during the sequencing process. Sequences that were found misplaced in the resulting gene tree (as, for example, species of one family grouped with species of a obviously non-related family) were re-sequenced or eliminated from subsequent analyses. Given the degree of redundancy in taxonomic sampling, errors can be detected when sequences from putative congeneric or conspecific specimens are not placed together in the tree. This procedure was conducted only to check sequence quality and by the end of the study we found 11 CytB, 19 Myh6, 18 Rag1, and 24 Rag2 suspicious sequences that were excluded from the analysis. Genetic distances among sequences were calculated in Mega 5.04 [39]. To evaluate the occurrence of substitution 
saturation, we estimated the index of substitution saturation (Iss) in DAMBE 5.2.31 [40], as described by Xia et al. [41] and Xia and Lemey [42]. To investigate the relative contribution of each gene to the final phylogeny obtained by maximum likelihood analysis, we did a partitioned branch support analysis (PBS, $[43,44]$ ) using the program TreeRot [45] with 20 replicate heuristic searches.

Maximum parsimony (MP) analyses were conducted with PAUP* 4.0b10 [46]. Heuristic searches were performed with minimally 1000 random addition replicates and TBR branch swapping. All characters were unordered, all character transformations were equally weighted, and branches with maximum length of zero were collapsed. Gaps were treated as missing data. Clade robustness was assessed using 1000 bootstrap pseudoreplicates [47] with the same parameters as above.

RAxML [37] using the web servers RAxML BlackBox [38] was used for all maximum likelihood analyses using a mixed partition model. Random starting trees were used for each independent ML tree search and all other parameters were set on default values. All ML analyses were conducted under GTR +G since RAxML only applies this model [37]. Topological robustness was investigated using 1000 non-parametric bootstrap replicates.

Phylogenetic analyses using a partitioned Bayesian approach (BA) were conducted in MrBayes 3.1.2 [48]. A mixed model analysis was implemented, allowing individual models of nucleotide substitution to be estimated independently for each partition. A set of six reasonable partitioning schemes, ranging from 1 to 13 partitions (Table 1), was tested following the procedures outlined by Li et al. [49] under the AIC and BIC criteria. The best-fit model of nucleotide substitution was calculated in Paup* 4.0b10 [46] with the program Modeltest 3.7 [50] under default parameters using the Akaike information criterion [51, for justification]. Because MrBayes
3.1.2 only implements 1,2 , and 6 substitutions rate models, often it was not possible to implement the preferred model as selected by the AIC. In these situations, the nearest overparameterized model was used to avoid negative consequences of model violation or underparameterization [52,53]. As a consequence, the model for all partitions was set as: "lset nst $=6$ " $(\mathrm{GTR}, \operatorname{TrN}$, TVM), "rates = invgamma" $(\mathrm{G}+\mathrm{I})$, and the commands "unlink" and "prset ratepr $=$ variable" were used to unlink model parameters across data partitions and define a rate multiplier for each partition. Two independent Bayesian analyses were conducted. Four independent MCMC chains were run with 30,000,000 replicates each, sampling one tree every 1000 steps. The distribution of log likelihood scores was examined to determine stationarity for each search and to decide if extra runs were required to achieve convergence, using the program Tracer 1.4 [54]. Initial trees estimated prior to convergence were discarded as part of a burn-in procedure, and the remaining trees were used to construct a 50\% majority rule consensus tree in Paup* [46].

Alternative phylogenetic hypotheses were compared using likelihood-based tests implemented in the program Treefinder [55]. These tests assess the statistical significance of differences in likelihood scores between two or more hypotheses. Probabilities for alternative hypotheses were obtained for the Shimodaira-Hasegawa $(\mathrm{SH})$ and the approximately unbiased (AU) tests $[56,57]$. Both testing procedures are adequate to compare hypotheses a posteriori based on the same data set, but since the $\mathrm{SH}$ test is more conservative [57], significance was determined when $\mathrm{P}$-values obtained were $\mathrm{P}<0.05$ and $\mathrm{P}<0.01$ for $\mathrm{SH}$ and $\mathrm{AU}$, respectively. Several hypotheses reflecting previous results (e.g., Lucena and Menezes [58], Calcagnotto et al. [32], Mirande [23]) and a set of alternative branching patters subtended by the basal nodes of the phylogeny obtained in this study were tested. Alternative hypotheses were constructed by performing tree-searches under specific topological

Table 1 Comparison of log likelihoods, AIC and BIC values among different partitioning schemes (from 1 to 13 partitions)

\begin{tabular}{|c|c|c|c|c|c|}
\hline Number of partitions* & number of parameters & $L_{M L}$ & AIC & $\Delta \mathbf{i}$ & $\mathrm{BIC}_{M L}$ \\
\hline 1 & 9 & 164,396 & 328,810 & 9894.730 & 328,825 \\
\hline 2 & 19 & 162,890 & 325,819 & 6903.326 & 325,850 \\
\hline $4 \mathrm{~A}$ & 39 & 163,108 & 326,295 & 7379.667 & 326,360 \\
\hline $4 \mathrm{~B}$ & 39 & 161,931 & 323,941 & 5026.042 & 324,006 \\
\hline 5 & 49 & 162,673 & 325,445 & 6529.681 & 325,527 \\
\hline 13 & 129 & 159,328 & 318,915 & 0.000 & 319,131 \\
\hline
\end{tabular}

For each type of analysis the following results are shown: total number of parameters; log likelihood calculated using RAxML $\left(L_{M L}\right)$; $A I C$ values; the difference in $\mathrm{AIC}$ values among model $\mathrm{i}$ and the best model $(\Delta i=\mathrm{AIC} i-\mathrm{AICmin}) ; \mathrm{BIC}_{M L}$ values.

*1 partition = all dataset; 2 partitions = mitochondrial $(16 \mathrm{~S}+$ CytB) and nuclear (Myh6 + Rag1 + Rag2); 4 partitions A = 16S and 1st, 2nd, and 3rd codon position of protein coding genes; 4 partitions $B=16 \mathrm{~S}+\mathrm{CytB}$ and $1 \mathrm{st}$, 2nd, and 3rd codon position of nuclear genes; 5 partitions = by each gene (16S + CytB + Myh6 + Rag1 + Rag2); 13 partitions = $16 \mathrm{~S}+$ each codon position of each protein coding genes (1st, 2nd, and 3rd codon position of CytB; 1 st, 2 nd, and 3rd codon position of Myh6; 1st, 2nd, and 3rd codon position of Rag1; 1st, 2nd, and 3rd codon position of Rag2). 
constraints to find the ML tree that satisfies the branching pattern enforced. The constraints either fixed the topology or the composition for major clades, but in each case multifurcations within these clades or elsewhere in the tree were resolved by the tree search. Searches were conducted under ML using the program Treefinder with a 13-partition scheme and a GTR+G model independently optimized for each partition (the same approach used with RAxML). Results from each of these constrained tree searches were saved individually and subsequently joined into a single hypothesis file to perform the topology tests according to the Treefinder manual [55].

\section{Results}

Partial sequences of two mitochondrial (16SrRNA and Cytb) and three nuclear genes (Myh6, Rag1 and Rag2) were obtained for 213 specimens (Additional file 3). The final matrix was deposited in TreeBase http://www.treebase.org under number 11474. Missing data, due to problems with PCR experiments, sequencing, or missing data in Genbank, corresponded to $11.7 \%$ of the total data set (Table 2). Data absence was more prevalent among nuclear (16.6\% missing) than mitochondrial genes (5.0\% missing), perhaps due to non-conserved priming regions and higher risk of cross-contamination in the nested PCR procedure. For each gene, the number and percentage of sequences obtained, their size (bp), number of variable sites, base pair composition, overall mean genetic distance (p-distance), the best substitution model for the gene, $\alpha$ (shape) parameter of $\Gamma$ distribution, proportion of invariants (I) sites, number of informative characters under parsimony, and proportion of informative characters under parsimony are presented in Table 2. Under the MP criterion, about one-half of the positions were phylogenetically informative. The overall mean of genetic distance observed was between $0.087 \pm 0.005$ (Myh6) to $0.208 \pm 0.007$ (CytB), suggesting that the analyzed sequences have enough genetic variation for the phylogenetic studies of species, genera and families. Each gene and codon position partition was tested further to investigate the occurrence of substitution saturation [41,42], and the results showed that there is significant saturation only for the Rag2 3rd codon positions in the asymmetrical topology test (results not shown); however, considering that the Iss.c value is greater than the Iss value the information found in this position can be used in the phylogenetic analysis $[41,42]$. The best-fitting model of nucleotide substitution calculated for each partition was: GTR $+\mathrm{I}+\Gamma(\mathrm{CytB} 1 \mathrm{st}$ and 2nd position, Myh6 1st and 2nd position, Rag1 1st position), TVM+I+F (Myh6 3rd position, Rag1 2nd position, Rag2 1st position), K81uf $+\mathrm{I}+\Gamma$ (Rag2 2nd position, Rag2 3rd position), $\mathrm{TIM}+\mathrm{I}+\Gamma$ (CytB 3rd position), $\operatorname{TrN}$ $+\mathrm{I}+\Gamma$ (Rag1 3rd position).

The combined data set contains significant phylogenetic information, given that most major lineages along the backbone of the tree were supported by high bootstrap values (> 70\%). A partitioned Bremer support analysis was applied to the maximum likelihood majority rule consensus tree. The results show many positive scores, indicating positive contribution and some negative scores indicating conflicting signal for particular nodes. In general, the positive contributions were higher for the mitochondrial genes (especially $16 \mathrm{~S}$ ), than for nuclear genes (Table 3).

Six different partitioning schemes, ranging from one to 13 partitions (Table 1), were tested to establish the

Table 2 Information content and characteristics of each gene partition

\begin{tabular}{|c|c|c|c|c|c|}
\hline & \multicolumn{5}{|c|}{ Gene } \\
\hline & $16 S$ & CytB & Myh6 & Rag1 & Rag2 \\
\hline Number of sequences & $213(100 \%)$ & $192(90 \%)$ & $178(84 \%)$ & $175(82 \%)$ & $182(85 \%)$ \\
\hline bp after alignment & 633 & 992 & 755 & 1266 & 1034 \\
\hline Number of variable sites & 357 & 636 & 377 & 835 & 680 \\
\hline $\begin{array}{c}\text { Number of informative characters under } \\
\text { parsimony }\end{array}$ & 298 & 556 & 314 & 645 & 574 \\
\hline$\%$ informative characters under parsimony & 47.07 & 56.04 & 41.59 & 50.94 & 55.51 \\
\hline$\Pi_{\mathrm{A}}$ & 0.2584 & 0.3472 & 0.3137 & 0.3059 & 0.2702 \\
\hline$\Pi_{\mathrm{C}}$ & 0.2186 & 0.3516 & 0.2205 & 0.1971 & 0.1961 \\
\hline$\Pi_{\mathrm{G}}$ & 0.1813 & 0.0623 & 0.1945 & 0.1947 & 0.2173 \\
\hline$\Pi_{\top}$ & 0.3418 & 0.2389 & 0.2713 & 0.3022 & 0.3164 \\
\hline Overall mean genetic distance ( $p$-distance) & $\begin{array}{l}0.124 \pm \\
0.007\end{array}$ & $\begin{array}{l}0.208 \pm \\
0.007\end{array}$ & $\begin{array}{l}0.087 \pm \\
0.005\end{array}$ & $\begin{array}{l}0.111 \pm \\
0.005\end{array}$ & $\begin{array}{l}0.115 \pm \\
0.004\end{array}$ \\
\hline Nucleotide substitution model & GTR & GTR & TrN & TVM & TVM \\
\hline$\alpha$ (shape) parameter of $\Gamma$ distribution & 0.60 & 0.42 & 1.04 & 0.88 & 1.00 \\
\hline Proportion of invariants (I) sites & 0.42 & 0.37 & 0.48 & 0.32 & 0.29 \\
\hline
\end{tabular}


Table 3 Results of the partitioned Bremer support (PBS) analysis showing the percentage of nodes with positive values, indicating net positive contribution, observed for each gene in the final majority rule consensus ML tree

\begin{tabular}{lccccc}
\hline & 16S & CytB & Myh6 & Rag1 & Rag2 \\
\hline All nodes & 84.1 & 75.6 & 70.7 & 42.7 & 41.5 \\
Familial nodes & 85.7 & 71.4 & 81.0 & 57.1 & 42.9 \\
Suprafamilial nodes & 76.5 & 70.6 & 64.7 & 47.1 & 35.3 \\
Infrafamilial nodes & 86.4 & 79.5 & 68.2 & 34.1 & 43.2 \\
\hline Mean & 83.2 & 74.3 & 71.2 & 45.3 & 40.7 \\
\hline
\end{tabular}

optimal number of data partitions (following Li et al. [49]) for the final analysis. The results showed that the 13 partition model was the best choice (Table 1); however, ML analysis conducted with the other partitioning schemes resulted in the same final topology, with minor differences in branch length and support values (not shown).

Throughout the text and in the figures, measures of support are indicated as a series of three numbers on selected internal branches of the trees subtending labelled clades, starting with posterior probabilities in Bayesian analysis (B) and followed by non-parametric bootstrap percentages from ML and MP analyses, respectively (e.g. 0.9/87/75, see Figure 4), dashes represent values lower than 0.5 (B) or $50 \%$ (ML, MP), and asterisks represent nodes that were not obtained by $\mathrm{B}$ or MP analyses. Nodes without support values greater than 0.5 (B) or $50 \%$ (ML, MP) were collapsed in all trees. A ML tree summarizing the phylogenetic results is presented in Figure 4. The general tree topology observed

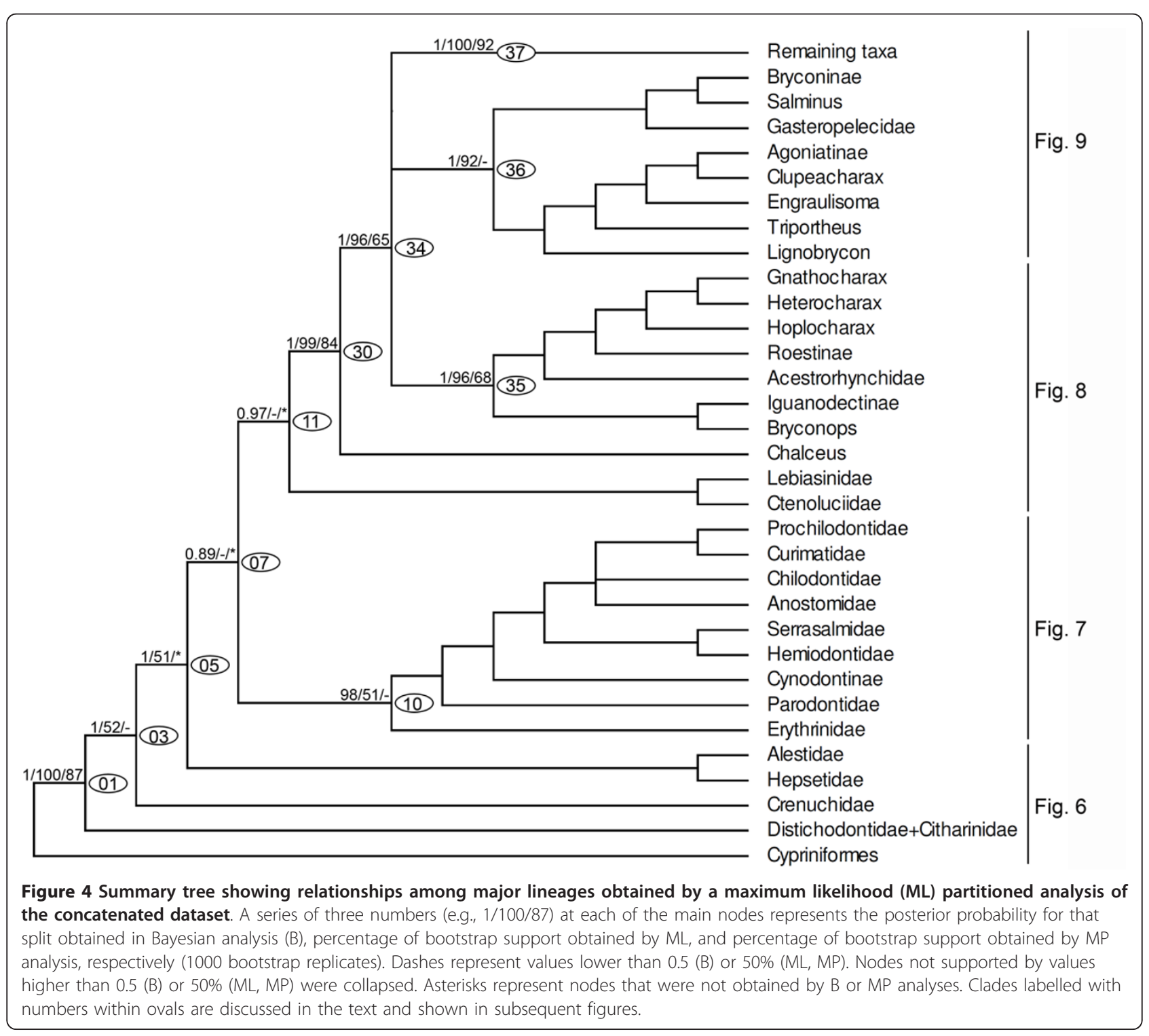


in all analyses was very similar, although statistical support was not strong for some nodes. An important difference between results of $B$ and ML versus MP analyses was that under MP, the Neotropical Ctenoluciidae appeared as sister group of the African Hepsetidae (instead of sister to Lebiasinidae as in Figure 4), however this hypothesis has low statistical support in the MP analysis (Figure 5). Since the most highly resolved topology was obtained by ML analysis, this topology will be used to discuss relationships among taxa (Figures. 4, $6,7,8,9,10,11,12,13)$, but important differences with results obtained by $\mathrm{B}$ and MP analyses will be discussed in the text. For convenience, clades discussed in the text also are labelled with numbers in the figures. Base composition was computed for all taxa on the concatenated alignment excluding constant sites to gauge the effect of

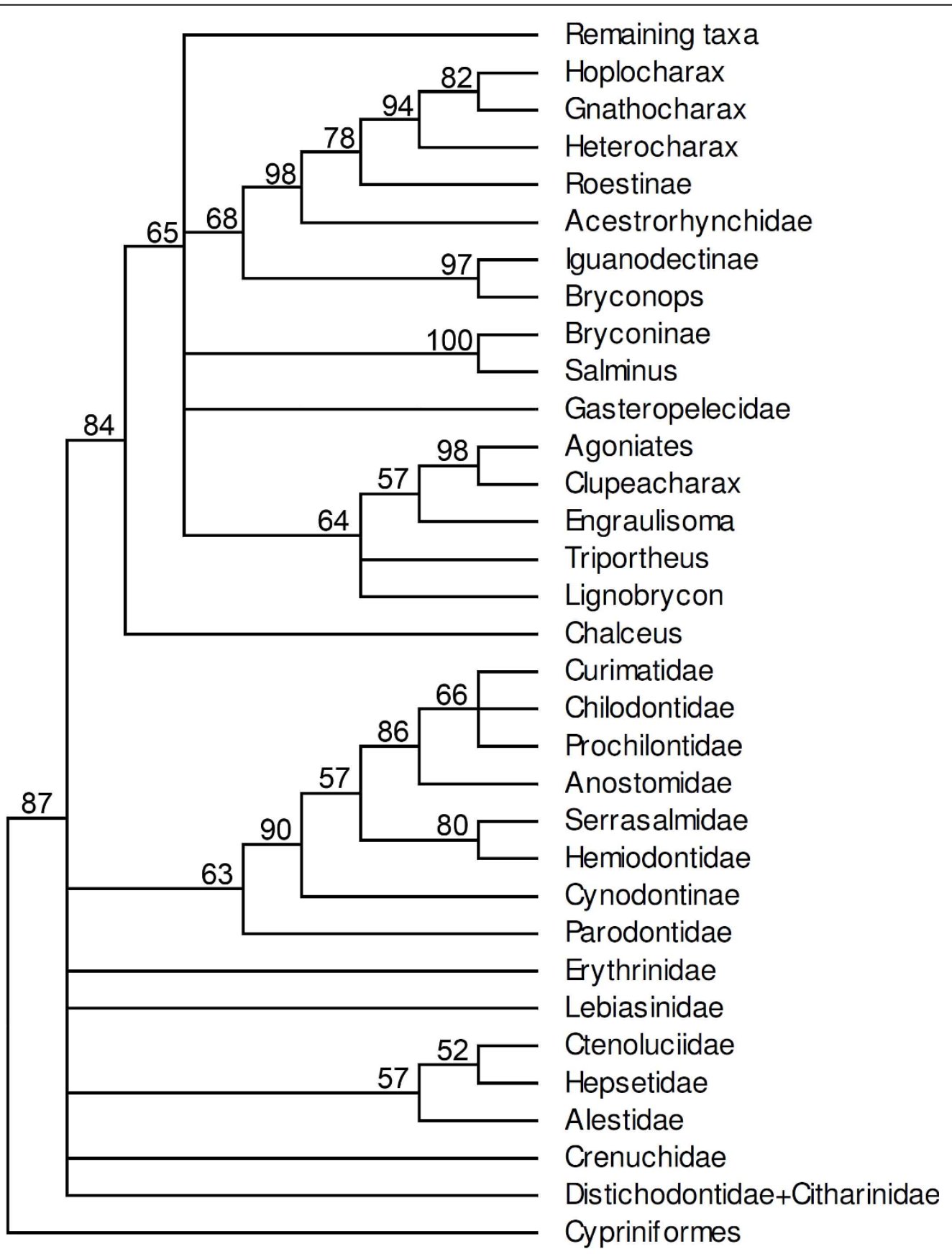

Figure 5 Majority-rule consensus tree obtained in maximum parsimony analysis, showing an alternative hypothesis of relationships among some characiform families. Numbers at nodes represent bootstrap supports. 
possible base compositional bias on the resulting phylogeny. The percent of $\mathrm{G}+\mathrm{C}$ (GC content) among 2885 variable sites was relatively homogeneous, ranging between $41.6 \%$ to $53.6 \%$, but only few taxa had extreme values. For example, sequences with the lowest GC content (lower than 46\%) were found among 12 taxa that are placed widely apart in the resulting phylogeny (e.g. Phenagoniates, Catoprion, Crenuchus). Likewise, sequences with the highest GC content (higher than 52\%) were found in taxa such as Cyanocharax, Xenocharax, Hollandichthys, Cheirodon, Cynopotamus, and Chalceus that also are nested in widely separate clades. Hence, base compositional bias as a source of systematic error does not seem to affect the phylogenetic results.

\section{Phylogenetic relationships}

Although a test of the monophyletic nature of the Characiformes was not the objective of the present study, rooting the tree in the Cypriniformes resulted in the Characiformes (clade 01) appearing as a well supported monophyletic group (values representing B posterior probability/MP bootstrap/ML bootstrap are: 1/100/87) in all analyses (Figure 4). Within the Characiformes, the African families Citharinidae and Distichodontidae (Figure 6 , clade $02,1 / 78 / 68$ ) form the sister group to all remaining members of the order (clade 03). Although the clade formed by those two families has been found in all analyses, monophyly of the Distichodontidae was not supported by the data since Citharinus (Citharinidae) is embedded within that family (Figure 6).

Clade 03 (Figures 4, 6, 1/52/-) is composed by the Crenuchidae (clade 04) plus all remaining components of the Characiformes (clade 05). The monophyly of the Crenuchidae was strongly supported (Figure 6, 1/100/ 99) and the data show a clear separation of Crenuchus and Poecilocharax, subfamily Crenuchinae (1/100/100), from Characidium and Melanocharacidium, subfamily Characidiinae (1/100/100). Characidium, however, was not supported as a monophyletic group, since Melanocharacidium is nested within it (Figure 6).

Although clade 05 (Figure 6, 1/51/*) is not unanimously supported in all analyses, it contains a well-supported group (Figure 6, clade 06, 1/98/57) that includes the African families Hepsetidae (clade 08, a single

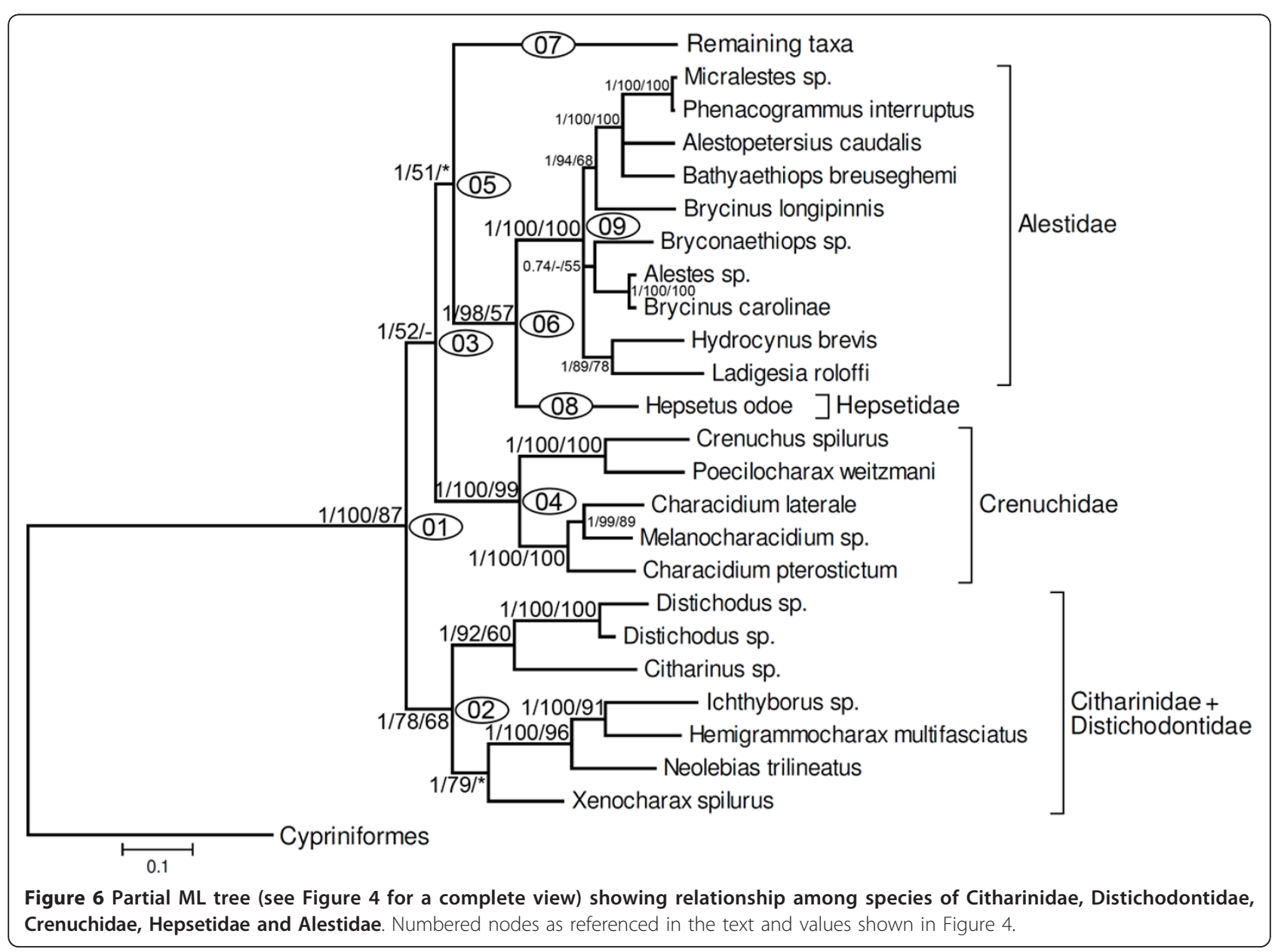


specimen analyzed) and Alestidae (clade 09, 1/100/100). These two families are the sister group to the remaining taxa (clade 07, Figure 4, 0.89/-/*), but note that this topology only received marginal support from Bayesian analysis.

Clade 07 (Figure 4) is composed by two major groups, clades $10(0.98 / 51 /-)$ and $11\left(0.97 / / /^{*}\right)$ none of which received unanimous support. Clade 10, however, is formed by several readily recognized and well-supported characiform families (Figures 4, 7). Within this clade, the Erythrinidae (clade 12, 1/99/100) is the sister group of all remaining members (Figure 7, clade 13, 1/ 88/63), and has Hoplias as the sister group of Erythrinus plus Hoplerythrinus. Among the remaining taxa in clade 13, the Parodontidae (clade 14, 1/100/100) form the sister group to clade $15(1 / 100 / 90)$, a well

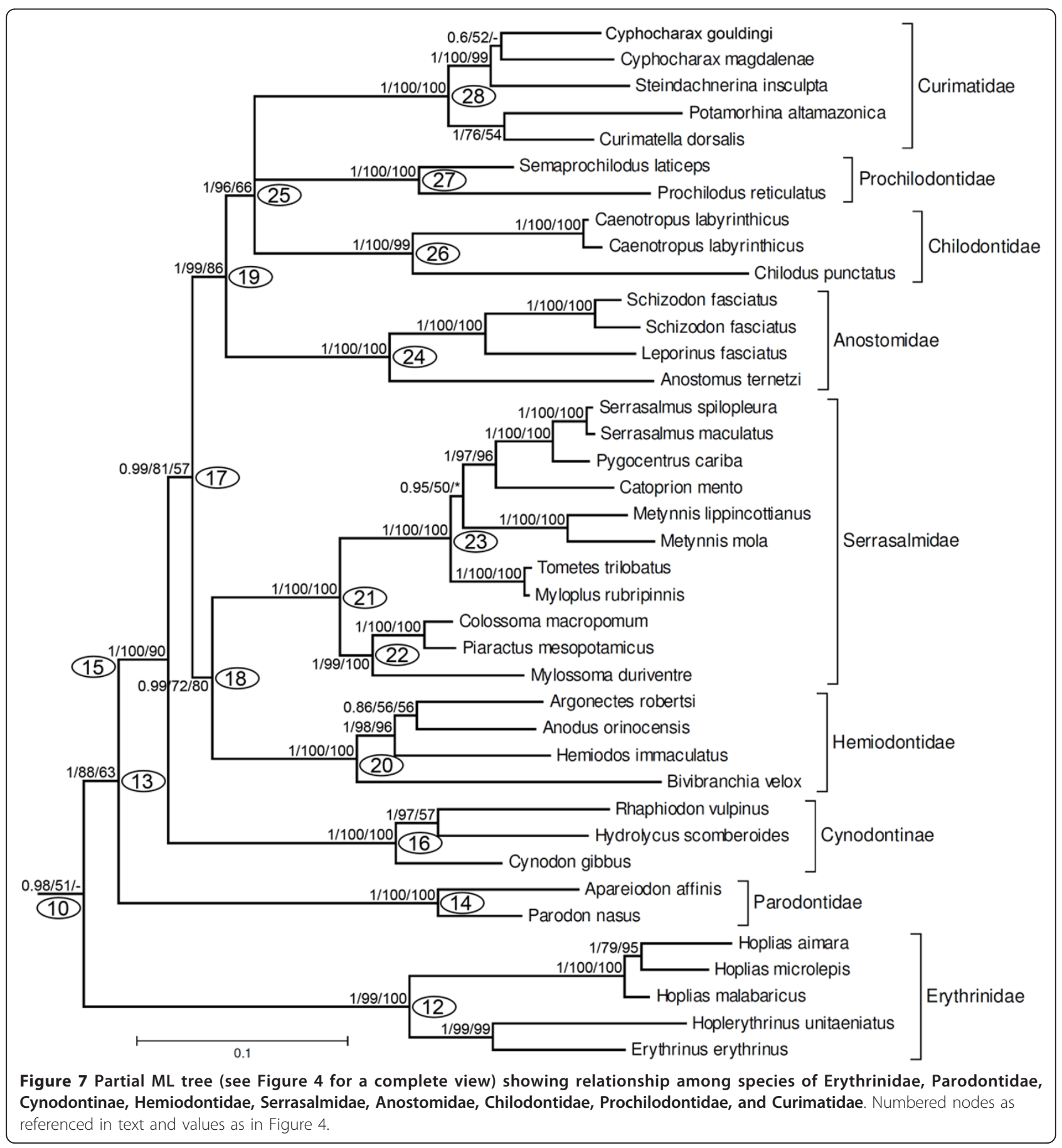


supported group that includes the characid subfamily Cynodontinae (Figure 7, clade 16, 1/100/100), represented by all three of its recognized genera. Cynodontinae is the sister group to all remaining taxa in this clade (Figure 7, clade 17, 0.99/81/57). These remaining taxa within clade 17 are split into two well supported groups. One of these groups is clade 18 (Figure 7, $0.99 / 72 / 80$ ) composed of the Hemiodontidae plus Serrasalmidae. The other group is the "Anostomoidea" (clade 19, 1/99/86), previously obtained by Vari $[9,26]$, Buckup [8] and Calcagnotto et al. [32], and composed by the families Anostomidae, Chilodontidae, Prochilodontidae and Curimatidae, all of which receive unanimous support, however, their reciprocal interrelationship could not be solved herein.

The second group within clade 07 is clade 11 (Figures $\left.4,8,0.97 / / /^{*}\right)$, obtained by ML, but only supported by a significant Bayesian probability. It is composed by the clade $29(1 / 61 /-)$ formed by the families Ctenoluciidae (clade 31, 1/98/99) and Lebiasinidae (clade 32, 1/100/
$100)$, and clade 30 , that received strong support in all analyses (1/99/94). Within clade 30, the genus Chalceus (clade 33, 1/100/100) is the sister group of all remaining taxa (Figure 8, clade 34, 1/96/65).

Clade 34, although well supported (1/96/55), includes three monophyletic subunits, clades 35 (1/96/68), 36 (1/ $92 /-)$, and $37(1 / 100 / 92)$ whose relationships were not resolved (Figure 4). Clade 35 is itself split into two well supported groups. One of them is clade 38 (1/100/97) composed by the Iguanodectinae and Bryconops affinis, and the other group is clade $39(1 / 100 / 98)$ that contains the Acestrorhynchidae, Roestinae and a well supported group (clade 43, 1/97/94) with Hoplocharax goethei, Heterocharax macrolepis and Gnathocharax steindachneri. Some differences from the ML topology shown in Figures 4 and 8 were obtained by MP analysis, where Gnathocharax and Hoplocharax are sister taxa (Figure 5). In the Bayesian analysis, the Acestrorhynchidae appeared as the sister group of Roestinae (with low posterior probability $=0.71$ ).

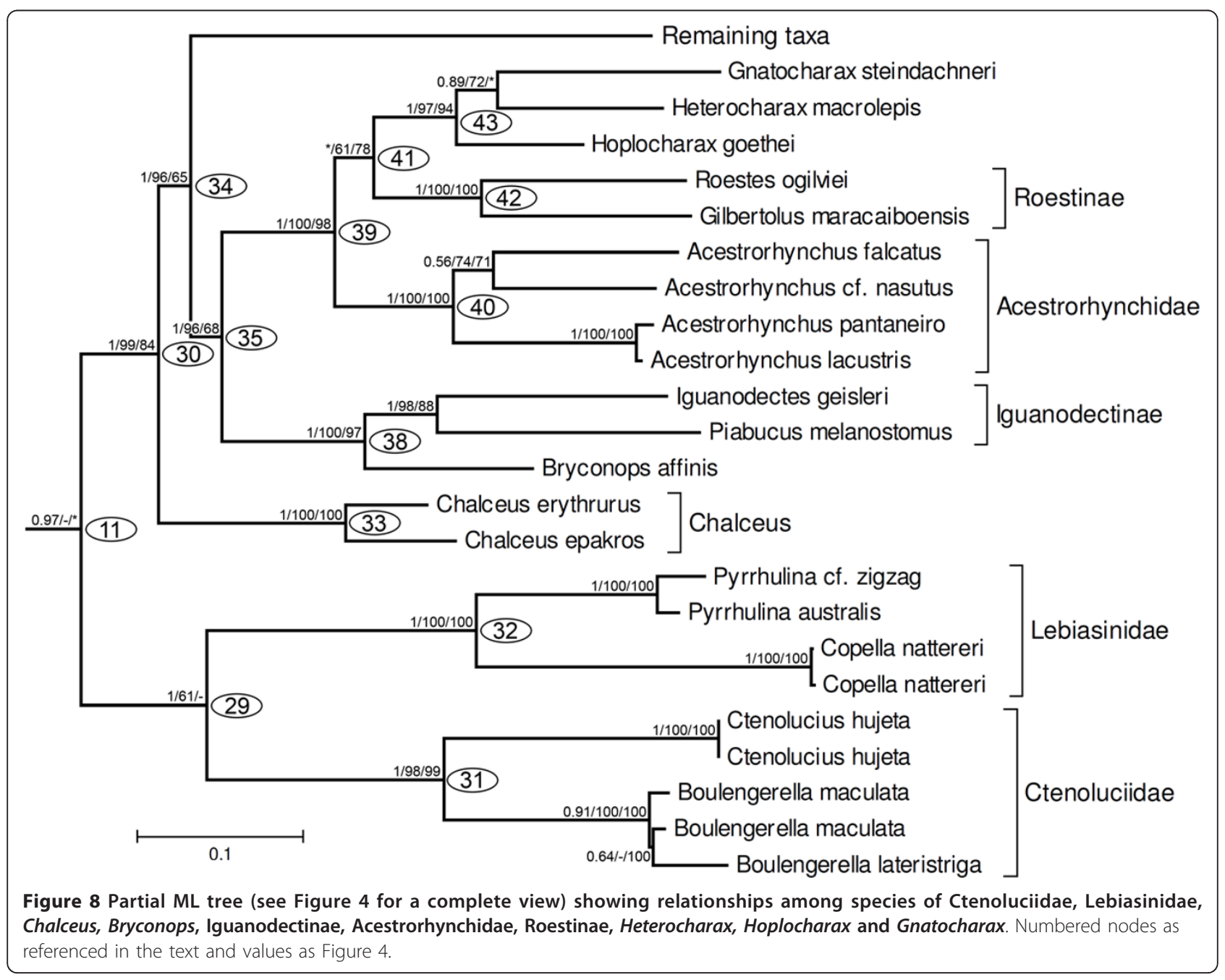


Clade 36 includes two monophyletic units (Figure 9, $1 / 92 /-)$. Clade $44(1 / 100 / 64)$ formed by representatives of the characid subfamilies Triportheinae (Lignobrycon myersi and Triportheus), Clupeacharacinae, and the Agoniatinae and the incertae sedis characid Engraulisoma taeniatum. Clade $45(0.97 / 77 /-)$ is formed by the distinctive family Gasteropelecidae (clade 46, 1/100/100) and clade $47(1 / 100 / 100)$ by the characid subfamily Bryconinae plus Salminus.

Clade 37 is very well supported (1/100/92) and composed by four monophyletic groups. The first is the genus Spintherobolus (Figure 9, clade 50, 1/100/100). This is a striking phylogenetic placement, since Spintherobolus was until now considered a component of the characid subfamily Cheirodontinae, but the other putative members of this subfamily are nested within clade 77 (Figure 11), one of the groups nested in clade 53. Spintherobolus is the sister group of clade 51 (Figure
$9,1 / 89 /-)$, composed by three monophyletic units, clade 52 that is the sister group of the monophyletic unit composed by clades 54 and 55 (Figure 9). Clade 52 (Figure 10,1/100/100) includes elements of the subfamilies Stethaprioninae, Rhoadsiinae and species of other 29 genera such as Gymnocorymbus, Nematobrycon, Moenkhausia, and Oligosarcus. Within this group also are placed species of Astyanax, Hemigrammus, Hyphessobrycon, and Jupiaba but the monophyly of these genera is not supported by the results.

Within clade 54 (Figure 11, 1/68/*), Exodon paradoxus and Roeboexodon guyanensis form the sister group to two species of Tetragonopterus (clade 73), the only genus in the Tetragonopterinae, plus Microschemobrycon casiquiare, and five genera of the Characinae (clade 75). Microschemobrycon casiquiare appears as the sister group of all the Characinae (Figure 11, clade 74, 1/100/ 100). In all analyses, the monophyly of the Characinae

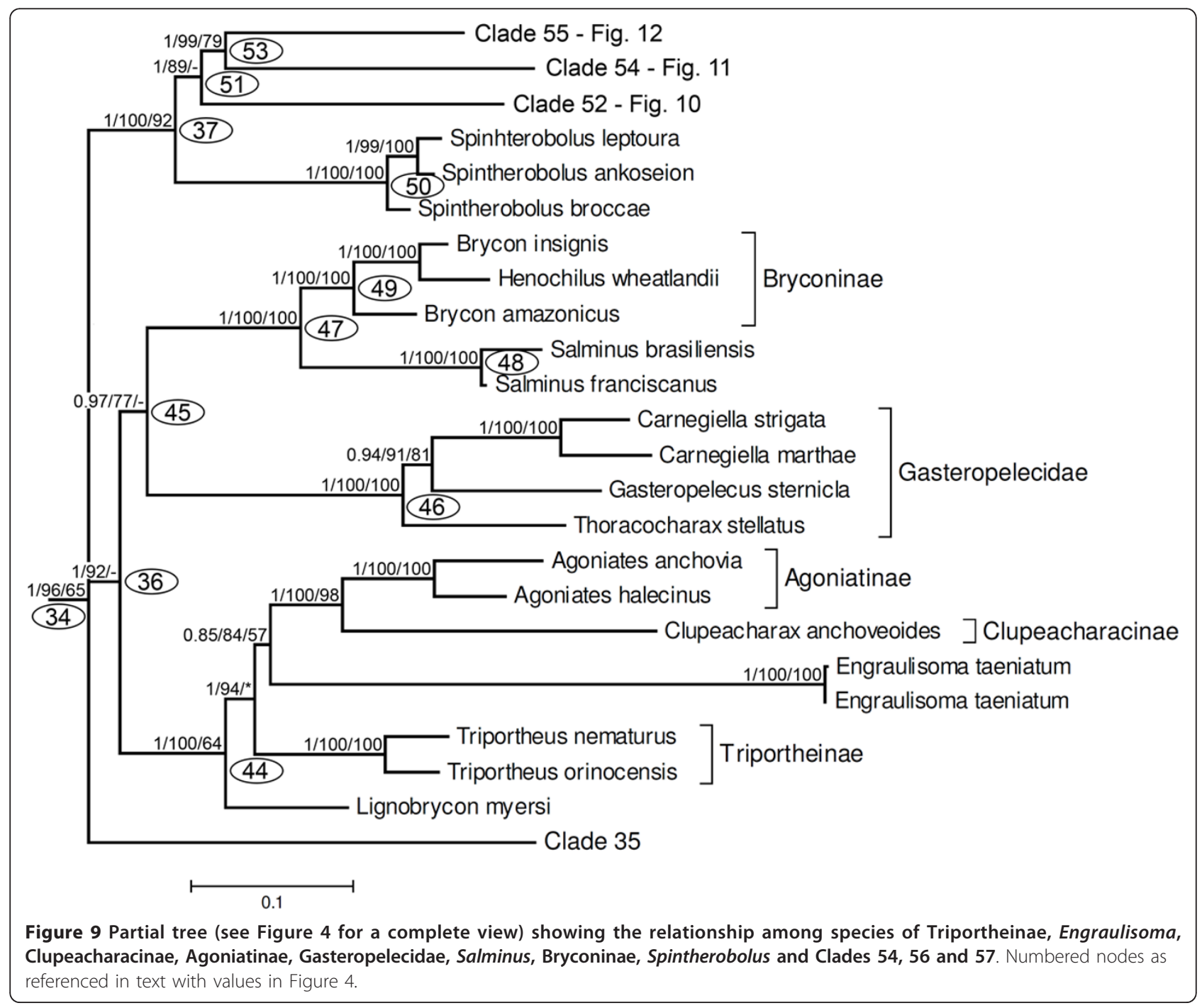




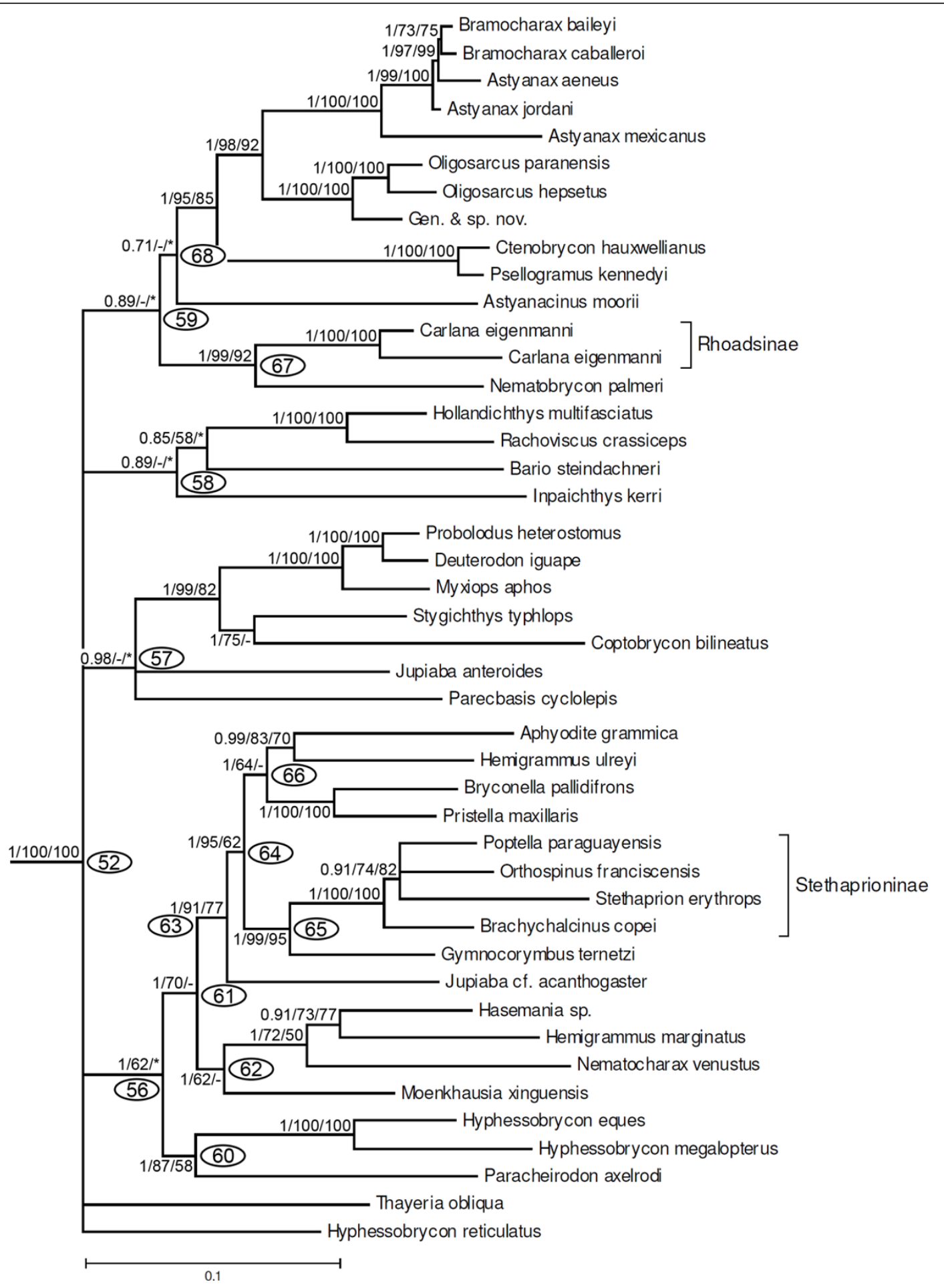

Figure 10 Partial ML tree (see Figure 9 for overall view) showing relationships among species of the clade 54, including Stethaprioninae, Rhoadsiinae and several genera previously considered incertae sedis in Characidae. Numbered nodes as referenced in text and values as in Figure 4.

was refuted due the association of Hoplocharax, Heterocharax and Gnatocharax (clade 43) previously assigned to this subfamily within clade 41 (Figure 8 , discussed above). Within clade 70 are all examined representatives of the subfamily Cheirodontinae (clade 77, 1/100/100) except for Spintherobolus (as noted above), and clade 76 


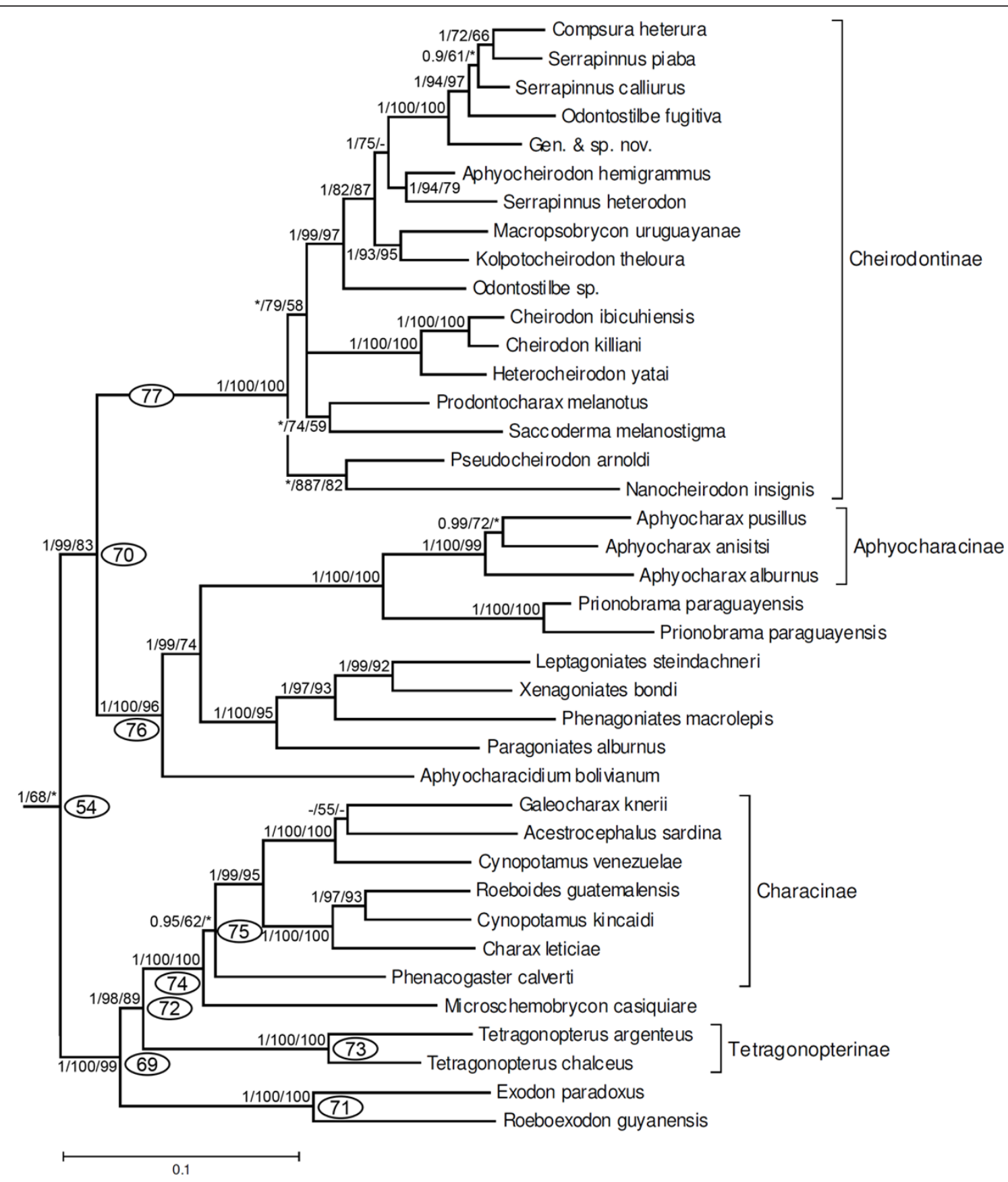

Figure 11 Partial ML tree (see Figure 9 for overall view) showing relationships among species of the clade 56, including Cheirodontinae, Aphyocharacinae, Characinae, Tetragonopterinae and several genera previously considered incertae sedis in Characidae. Numbered nodes as referenced in text and values as in Figure 4.

$(1 / 100 / 96)$ that includes the three examined members of the subfamily Aphyocharacinae and the genera Aphyocharacidium, Paragoniates, Phenagoniates, Xenagoniates, Leptagoniates and Prionobrama, all presently considered incertae sedis in the Characidae.

The final group in clade 37 consists of what has most recently be considered to be the Stevardiinae according to Mirande [23]; albeit with the addition of Markiana nigripinnis which that author has as part of the Astyanax clade within the Characidae. These results differ from those of the earlier study by Weitzman et al. [20] under which the members of their more restricted Stevardiinae fall into different subunits of clade 55 (Figure 12). These are clade $80(1 / 100 / 100)$ including 


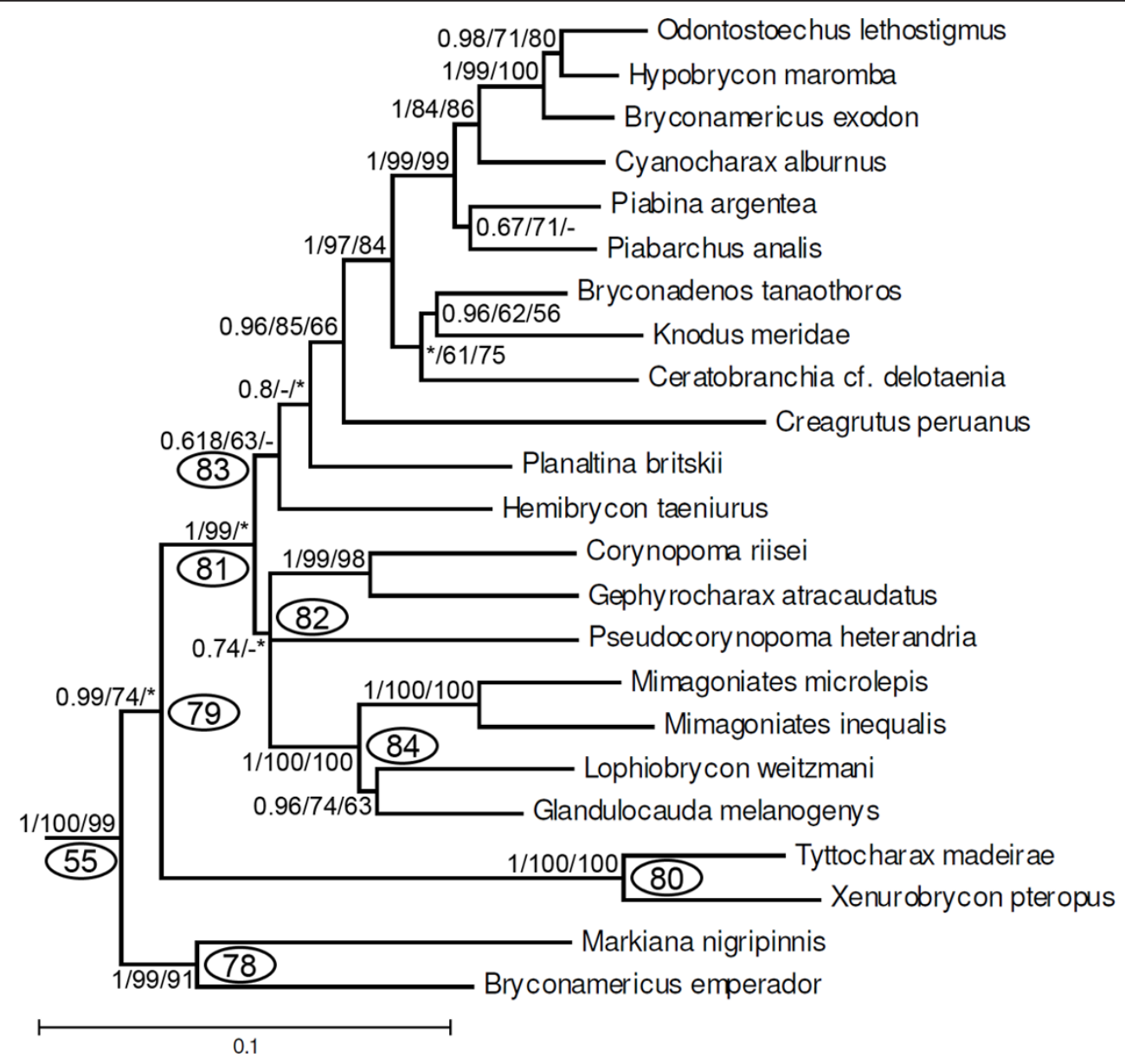

Figure 12 Partial ML tree (see Figure 9 for overall view) showing relationships among species of the clade 55 (subfamily Stevardiinae) Numbered nodes as referenced in text and values as in Figure 4.

Tyttocharax madeirae and Xenurobrycon pteropus, part of clade 82 formed by Corynopoma riisei, Gephyrocharax atracaudatus, Pseudocorynopoma heterandria, and by Planaltina which is located inside clade 83 . The Stevardiinae of Weitzman et al. [20] additionally differs from clade 55 in not including representatives of Bryconamericus, Bryconadenos, Ceratobranchia, Creagrutus, Cyanocharax, Hemibrycon, Hypobrycon, Knodus, Odontostoechus, Piabarchus, and Piabina all of which were considered incertae sedis in the Characidae by Lima et al. [29]. In the analysis, Bryconamericus emperador does not form a monophyletic group with $B$. exodon, the type species of this genus, a result indicating the non-monophyly of the genus.

Some key alternative hypotheses were tested to assess their support in light of the new molecular evidence. The topologies derived from studies by Lucena and Menezes [13], Calcagnotto et al. [32], and Mirande $[22,23]$ produced likelihood scores that are significantly worse than the score of the ML tree $(\operatorname{lnL}=-159175.3$ obtained with Treefinder), and are therefore rejected by the new data (Table 4). However, the ML tree (summarized in Figure 4) and several topologies with alternative branching patterns among at the basal-most nodes are statistically indistinguishable under maximum likelihood (Table 4). Ln Likelihood differences of up to 40 units from the ML tree score are not significantly rejected by the $\mathrm{SH}$ and $\mathrm{AU}$ tests. A set of nine topologies tested involve alternative placements among the following early-branching lineages of Characiformes: Distichodontidae + Citharinidae (clade 02), Crenuchidae (clade 04), Alestidae + Hepsetidae (clade 06), Parodontidae (clade 14), Erythrinidae (clade 12), Lebiasinidae (clade 32), Ctenoluciidae (clade31) and clade 15 (Cynodontidae, Anostomoidea, Serrasalmidae and Hemiodontidae). Although an exhaustive search of all possible trees with alternative branching patterns of these lineages was not performed, results from the tested topologies show that at least five of the nine trees cannot be rejected under this criterion. This result is consistent with the low support values 
obtained for clades 03, 05, 07, 10, 11, 13, and 29 (Figures $4,5,6,7,8)$. Therefore, the relative position of these groups remain unresolved in our study, as reflected in Figure 13. Interestingly, a topology that reflects reciprocal monophyly of African and Neotropical groups obtained a LnL score only 37.2 units worse from the ML score and is only marginally worse than the ML topology.

\section{Discussion}

Although many important studies have been conducted to infer relationships among families in the Characiformes at different levels, this problem was previously only partially tested because of incomplete sampling across the order $[8,22,23,32,59]$ or due to a lack of resolution in the data [30]. But some consensus seems to be emerging [60]. The studies of Ortí and Meyer [30], Buckup [8], Calcagnotto et al. [32] and the present results (Figures 4,6) corroborate the hypothesis of Vari [25] that the Citharinidae and Distichodontidae form a monophyletic lineage and are the sister group to all other Characiformes. Topology tests suggest that alternative placement of this lineage cannot be rejected, and our data suggest that some components of the Distichodontidae (Distichodus) may be more closely related to the Citharinidae (Citharinus) than to other taxa now assigned to the Distichodontidae (Figure 6). This conclusion runs counter to the morphological evidence, in particular the very unusual mobile hinge between the dentary and more posterior components of the lower jaw [24] and should be further tested using additional taxa and molecular characters.

The second lineage observed in our results is the family Crenuchidae (Figures 4, 6). Up to this time, the position of the Crenuchidae among characiforms has been problematic (Figures 1, 2b) with different authors suggesting alternative phylogenetic placements $[8,23,30,32]$. Even though our results suggest that this group forms one of the early branching events within the order, support for this position is not strong and should be considered provisional. Only five taxa of the Crenuchidae were included in this analysis (Figure 6), but the monophyly and distinctiveness of these taxa received strong support in our study, as does its division into the subfamilies Crenuchinae and Characidiinae as proposed by Buckup [8]. On the other hand, the two analyzed species of Characidium did not appear as sister taxa, suggesting the genus may be polyphyletic (Figure 6) a hypothesis that should be tested in the future with additional data.

Results based on Bayesian and ML analyses strongly suggest a close relationship between the Alestidae and Hepsetidae (clade 06, Figures 4, 6), a conclusion at variance with hypotheses proposed by Ortí and Meyer [30],
Buckup [8], Calcagnotto et al. [32], and Zanata and Vari [5]. In our MP analysis the Hepsetidae appears, however, as the sister group of the Ctenoluciidae as proposed by Buckup [8]. Unfortunately, the backbone nodes in the phylogeny separating Hepsetidae and Ctenoluciidae (Figure 4) are all weakly supported by ML and MP analyses, and the topology tests suggest that alternative placements of this lineage are not significantly different (Table 4). Interestingly, our study (in agreement with Calcagnotto et al. [32], and Arroyave and Stiassny [61]) indicates that the Alestidae is not the sister group of Chalceus as proposed by Zanata and Vari [5] and Mirande $[22,23]$ based on morphological evidence.

All of the analyses in this study strongly support a large Neotropical clade composed by the "Anostomoidea" (Anostomidae, Chilodontidae, Curimatidae, Prochilodontidae), plus Cynodontinae, Serrasalmidae, Hemiodontidae (Figure 7, clade 15, 1/100/90). Although other authors suggested a close relationship among some of these families $[8,9,30,32]$ the final composition and arrangement of this group arrived at in

Table 4 Likelihood-based tests for alternative topologies

\begin{tabular}{ccccc}
\hline Topology $^{\text {a }}$ & Ln Likelihood & Diff. $^{\mathbf{b}}$ & SH & AU \\
\hline$(1,(2,(3,((4,(5,6)),((7,8), \mathrm{R})))))$ & -159175.3 & 0.0 & 1.0000 & 0.9139 \\
$(7,(1,(2,(3,(4,((5,6),(8, \mathrm{R})))))))$ & -159195.4 & 20.1 & 0.4269 & 0.2226 \\
$(1,(2,(7,(3,(4,((5,6),(8, \mathrm{R})))))))$ & -159195.7 & 20.4 & 0.4109 & 0.0514 \\
$(1,(7,(2,(3,(4,((5,6),(8, \mathrm{R})))))))$ & -159198.9 & 23.6 & 0.3037 & 0.0766 \\
$(7,(1,(2,(3,(6,(8,(5,(4, \mathrm{R}))))))))$ & -159200.5 & 25.2 & 0.2912 & 0.1972 \\
$(7,(1,(3,(2,(4,((5,6),(8, \mathrm{R})))))))$ & -159201.4 & 26.1 & 0.2531 & 0.0882 \\
$((1,3),(7,(2,((5,6),(8, \mathrm{R}))))))^{c}$ & -159212.5 & 37.2 & 0.1071 & $0.0000^{*}$ \\
$(7,(1,(2,(3,((4,6),(5,(8, \mathrm{R}))))))$ & -159215.6 & 40.3 & $0.0446^{*}$ & $0.0000^{*}$ \\
$(1,(2,(7,(3,(4,(5,(6,(8, \mathrm{R}))))))))$ & -159219.3 & 44.0 & $0.0371^{*}$ & $0.0000^{*}$ \\
$(1,(4,(7,(2,(3,(6,(8,(5, \mathrm{R}))))))))$ & -159220.9 & 45.6 & $0.0485^{*}$ & 0.0295 \\
Calcagnotto et al. [31]] & -159685.2 & 509.9 & $0.0145^{*}$ & $0.0000^{*}$ \\
Lucena and Menezes $[12]$ & -159692.4 & 517.1 & $0.0128^{*}$ & $0.0000^{*}$ \\
Mirande $[22]$, node 176 only & -160345.9 & 1170.6 & $0.0000^{*}$ & $0.0000^{*}$ \\
Mirande $[22]$ & -166637.0 & 7461.7 & $0.0000^{*}$ & $0.0000^{*}$ \\
\hline
\end{tabular}

$\mathrm{SH}$ and $\mathrm{AU}$ are probability values obtained for the Shimodaira-Hasegawa and the Approximately Unbiased tests (Shimodaira 2002). Asterisks denote significant values $(\mathrm{P}<0.05$ for $\mathrm{SH}$ and $\mathrm{P}<0.01$ for $\mathrm{AU})$, that imply the topology is rejected.

a Topologies are sorted by likelihood values (obtained with Treefinder); at the top is the unconstrained ML topology summarized in Figure 4. Alternative hypotheses tested are depicted by parenthetic notation, where numbers represent the following taxa: 1: Distichodontidae+Citharinidae, 2: Crenuchidae, 3: Alestidae+Hepsetidae, 4: Erythrinidae, 5: Parodontidae, 6: Cynodontidae +Anostomoidea+Serrasalmidae+Hemiodontidae, 7: Ctenoluciidae, 8: Lebiasinidae, R: the rest (node 31 in Figure 4). Other topologies tested were taken from Calcagnotto et al. (2005); Lucena and Menezes (1998): the monophyly of Cynodontidae according to these authors groups: Cynodon, Hydrolycus, Rhaphiodon, Gilbertolus, and Roestes; Mirande (2010): either his full cladogram or only a constraint to impose his node 176 (Salmininae, Agoniatinae, Acestrorhynchinae, Cynodontidae).

${ }^{\mathrm{b}}$ Difference in Ln likelihood score with the best tree and the alternative topologies tested.

c This topology is consistent with the reciprocal monophyly of African and Neotropical species. 


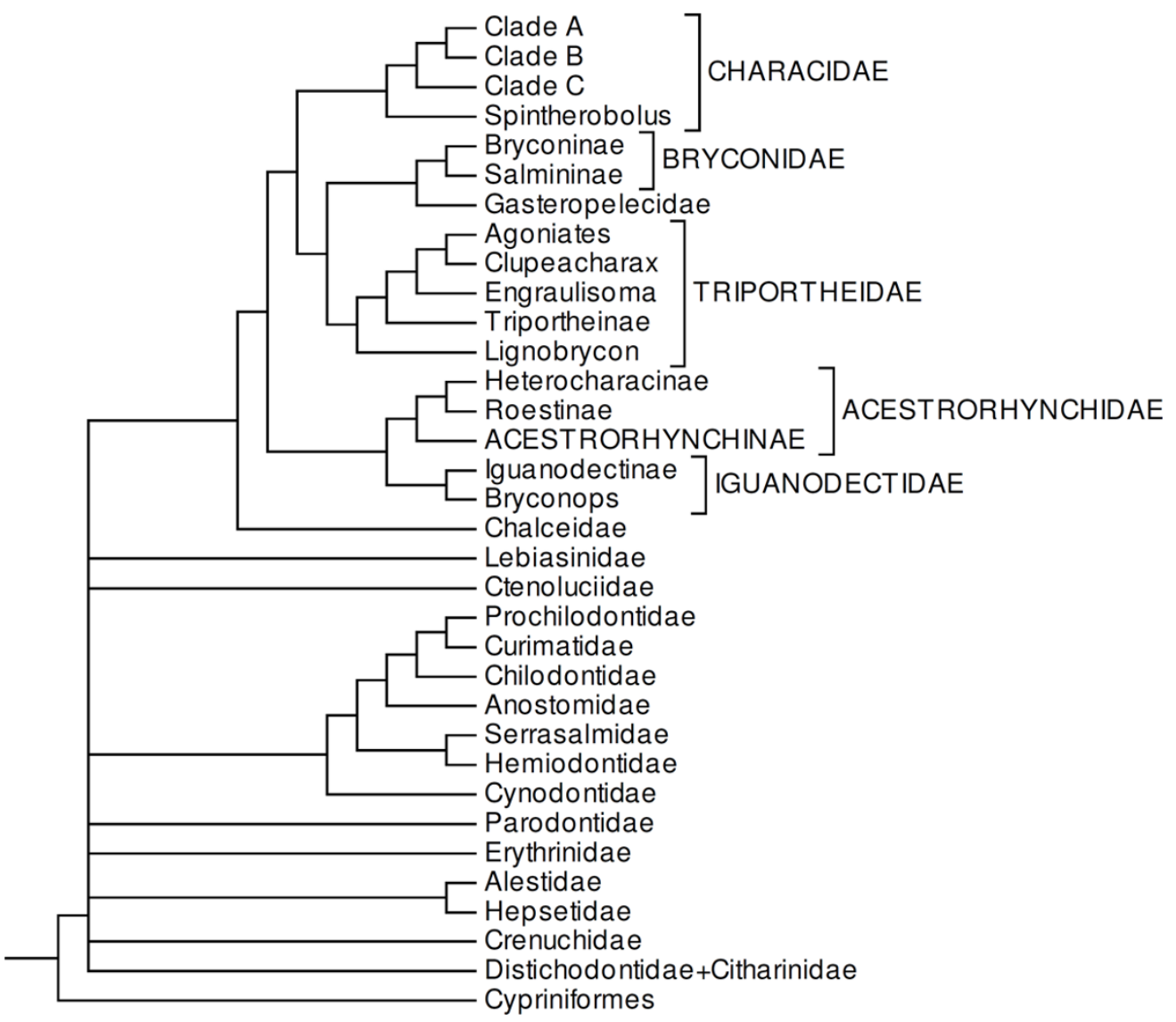

Figure 13 Tree of the Characiformes with modified familial-level concepts indicated in uppercase.

this study represents a novel hypothesis of relationship among these taxa. In some of our results, the Erythrinidae appears as the sister group of clade 13, (albeit with low support especially by ML and MP criteria), a hypothesis at variance with morphologically based studies which associated the family in varying combinations with the Ctenoluciidae, Hepsetidae and Lebiasinidae [62]. In contrast, Calcagnotto et al. [32] obtained support for a sister group relationship between the Erythrinidae and Crenuchidae. If supported by future studies our hypothesis would indicate that many of the apparent morphological synapomorphies among the Ctenoluciidae, Hepsetidae and Lebiasinidae may be convergences perhaps associated with modifications necessary for predatory life styles. At this stage, however, relationships among these early branching lineages of characiforms (Erythrinidae, Crenuchidae, Ctenoluciidae, Alestidae, Hepsetidae, Lebiasinidae, Parodontidae, and clade 15 ) remain poorly resolved. Our results, however, indicate that within the Erythrinidae, Erythrinus and Hoplerythrinus form a monophyletic group which is the sister group of Hoplias. This is the first published hypothesis of relationship among genera of the Erythrinidae and should be tested in further studies in this family.

The monophyly of Cynodontidae, as proposed by Lucena and Menezes [13], is rejected by our phylogenetic analysis and topology tests (Figure 6 and Table 4); instead, representatives of Roestinae (Roestes and Gilbertolus) are placed more closely related to the Acestrorhynchidae (Figure 8). The monophyly of the Cynodontinae as proposed by Toledo-Piza [17] was, however, corroborated but internal relationships among the genera of the Cynodontinae found in the present study differ, since herein we find Rhaphiodon and Hydrolycus as sister groups while Toledo-Piza [17] proposed Rhaphiodon as the sister group of Cynodon.

A sister group relationship between the Hemiodontidae and Serrasalmidae (clade 18, Figure 7) has never been proposed. Calcagnotto et al. [32], however, hypothesized that the Serrasalmidae forms the sister group of a clade consisting of five Neotropical families, one of which was the Hemiodontidae (Figure 1). The monophyly of the Hemiodontidae as proposed by Langeani [27] is corroborated. The piranhas and pacus form a distinct and strongly monophyletic group, historically 
considered a subunit of the Characidae; however, the distinctive external anatomy of the members of the serrasalmids [63] and its phylogenetic separation from other taxa typically associated with the Characidae lead various authors to consider this group as a family distinct from the Characidae (e.g., Ortí et al. [7]). Based on the arrived at scheme of relationships, and in order to keep the family Characidae monophyletic, we also recognize the family Serrasalmidae as valid. Although some genera and many species of the Serrasalmidae were not included in the present study, phylogenetic relationships within the family are in agreement with more detailed studies (e.g., Ortí et al. [7]).

The large assemblage composed by the Anostomidae, Chilodontidae, Prochilodontidae and Curimatidae supported in our results (Figures 4,7) is similar to that obtained by Vari [9] and corroborated by Buckup [8] based on data from Vari [9]. In light of an extensive series of unusual modifications of the gill arches and anterior portion of the vertebral column, Vari [9] found a close relationship between the Chilodontidae and Anostomidae. Herein, the position of the Chilodontidae was unresolved, thus, the hypothesis of Vari [9] about the pattern of relationships among these families should be tested in the future with the inclusion of more data and taxa.

\section{Monophyly and composition of Characidae}

At present two conflicting hypothesis are available regarding the family Characidae. A broad concept is that employed by Nelson [1] and Reis et al. [6] in which 12 subfamilies and about a hundred incertae sedis genera are included in this family. This concept is very close to that proposed by Mirande [22,23] that differs from the schemes of previous authors by the exclusion of Serrasalmidae from, and inclusion of the Acestrorhynchidae and Cynodontidae in, the Characidae (Figure 2). According to Mirande [23] this broad Characidae is characterized by eight synapomorphies, only one of which, the fusion of the anteriormost procurrent caudalfin rays into medial bony plates running parallel to the remaining rays (character 305), is an unreversed and uncontradicted synapomorphy of the Characidae. A more restricted concept of the Characidae is that proposed by Malabarba and Weitzman [19] according to whom this family is composed only by characiform species lacking the supraorbital bone (Figure 2). This restricted group is recognized by Mirande [22,23] who proposed that the absence of a supraorbital bone characterizes a monophyletic group of "distal" characids.

The present results could be interpreted in alternative modes taxonomically but in order to maintain the previously recognized families Cynodontidae, Acestrorhynchidae and Gasteropelecidae and in order to simplify the recognition of the family Characidae we suggest usage of a more restricted composition for this family, as described below.

Clade 30, a robust result in all analyses (Figures 4, 8), encompasses all species currently grouped in the Characidae (sensu Reis et al. [6]), with the exception of the Serrasalmidae but with the addition of the Gasteropelecidae, Acestrorhynchidae and Roestinae (a subfamily of the Cynodontidae sensu Lucena and Menezes [13]) (Figures 4, 5, 8). The genus Chalceus, previously placed with Alestidae by Zanata and Vari [5] and Mirande $[22,23]$ based on morphological features, was found here as the basal branch in clade 30, a hypothesis also congruent with results of Calcagnotto et al. [32]. Since Chalceus belongs to an important monophyletic lineage either as the sister group of a large assemblage of Neotropical characids, as proposed herein, or closely related to the Alestidae as suggested by the morphological analysis [5] we recognize the family Chalceidae in the sense of Albert et al. [64] consisting of the species of Chalceus, to highlight this phylogenetically significant monophyletic group (Figure 13).

Clade 35 (Figure 8) contains the representatives of Acestrorhynchidae, the subfamilies Iguanodectinae and Roestinae, some genera of Characinae and Bryconops. The Iguanodectinae (two valid genera) is placed as the sister group of Bryconops affinis (Figure 8). Mirande [23] also found a monophyletic Iguanodectinae closely related to a named 'Bryconops' clade. In order to recognize this monophyletic assemblage within the Characiformes, we propose that Iguanodectes, Piabucus and Bryconops be united in the family Iguanodectidae (Figure 13).

Acestrorhynchidae is placed as the sister group of the Roestinae, a subfamily that is presently assigned to the Cynodontidae, along with some species of the Characinae (Gnathocharax, Heterocharax, Hoplocharax) (Figure 8). A close relationship between the Acestrorhynchidae and Roestinae was previously proposed by Lucena and Menezes [13]. Alternatively, Malabarba and Weitzman [19] questioned the relationship between the Roestinae and Cynodontinae because of the presence in adults of Gilbertolus and Roestes of bony hooks on the fin rays versus the absence of those elaborations in the fins of Cynodon, Rhaphiodon and Hydrolycus. Our results indicate that the Cynodontinae and Roestinae are not closely related, refuting the monophyly of the Cynodontidae of Lucena and Menezes [13]. Mirande [22] found a monophyletic group composed by Acestrorhynchus pantaneiro and Rhaphiodon vulpinus (the only species of the Cynodontidae analyzed in that study), a hypothesis which is refuted in the present study since Rhaphiodon and the other two genera of the Cynodontinae, are grouped with high support in clade 10 (Figure 
7). Lucena [65] was the first author to propose the monophyly of a clade composed of Gnathocharax, Heterocharax, Hoplocharax and Lonchogenys. Mirande [22] found the same monophyletic group and proposed the subfamily Heterocharacinae to contain Gnathocharax (not studied by that author), Heterocharax, Hoplocharax and Lonchogenys. Although representatives of Lonchogenys were not analyzed in the present study, a monophyletic group formed by Gnathocharax, Heterocharax and Hoplocharax also was obtained in our results (clade 43, Figures 4, 5, 8). The genera Gnathocharax, Heterocharax, Hoplocharax and Lonchogenys were assigned to the Characinae by Lucena and Menezes [58] but differ from the other members of this subfamily in several synapomorphies [22,23]. Therefore, we suggest the retention of the Heterocharacinae (sensu Mirande [22]) to refer to taxa in clade 43. In order to delimit our clade 39 as monophyletic unit within characiforms we propose that the Acestrorhynchidae as currently defined [66] be ranked as a subfamily (Acestrorhynchinae); and the group composed by the Roestinae, Heterocharacinae (sensu [22]) and Acestrorhynchinae, as newly defined, form a more encompassing Acestrorhynchidae (Figure 13).

Another well supported group of note is clade 36 in which the Agoniatinae (both of the recognized species included in our analysis) forms a monophyletic lineage with the Clupeacharacinae (only one recognized species) and the group formed by these taxa is the sister group of Engraulisoma (a single described species). This monophyletic clade is, in turn, the sister group of Triportheus (two of nineteen species included) in the B and ML analyses (Figure 9) or as the sister group of the Triportheinae in the MP analysis (Figure 5). In the B and ML analyses Lignobrycon (a single Recent species) is the sister group of all remaining taxa in the clade 44 (Figures 4, 9). Relationships across the spectrum of these groups were not previously investigated since earlier phylogenetic studies involving characiforms and/or characids included only a few representatives from this clade $[22,23,30,32,33]$. Malabarba [15] found eight synapomorphies supporting a close relationship between Triportheus and Lignobrycon, but it is uncertain whether the intervening taxa in the phylogeny arrived at herein were considered in her analysis. It would be informative to revisit the morphological hypothesis within the context of the results arrived at herein. In order to highlight this monophyletic lineage we expand the Triportheinae to include the genera Agoniates, Clupeacharax, Triportheus, Engraulisoma, and Lignobrycon and recognize it as the Triportheidae (Figure 13).

The Gasteropelecidae (clade 46) is placed as the sister group of the Bryconinae plus Salminus (clade 47, Figures $4,5,9$ ), albeit without unanimous support. The three genera of the Gasteropelecidae formed a monophyletic group in which Carnegiella is the sister group of Gasteropelecus (Figure 9). In contrast, Javonillo et al. [33] found Thoracocharax to be the sister group of Gasteropelecus with Carnegiella the sister group of that clade. In his pre-cladistic analysis of the Gasteropelecidae, Weitzman [67] considered Carnegiella to be an evolutionary "development" of Gasteropelecus, mainly through structural losses. Subsequently Weitzman [68] stated that Thoracocharax has a "somewhat more primitive morphology with respect to other members of the Gasteropelecinae (= Gasteropelecidae)" and arose from a common ancestor with Gasteropelecus. He also proposed that Carnegiella "seems to be a neotenic form of Gasteropelecus and directly derived from it". Our results are, thus, congruent with the proposals of Weitzman $[67,68]$ but not the hypothesis of Javonillo et al. [33].

A close relationship between Brycon and Salminus (Figure 9) was recognized by Géry [63] who suggested that the tribe Salminini was part of the Bryconinae. This hypothesis was corroborated in the phylogenetic studies of Ortí and Meyer [30], Calcagnotto et al. [32], and Javonillo et al. [33]. Calcagnotto et al. [32] found that Salminus was placed inside Brycon and Javonillo et al. [33] found Salminus to be the sister group of the two analyzed species of Brycon. Herein, the monophyly of Brycon was rejected since $B$. insignis appeared more closely related to Henochilus wheatlandii than it is to $B$. amazonicus. This would indicate that further studies are necessary to determine whether Henochilus must be synonymized with Brycon I. Mirande [22] previously proposed the subfamily Salmininae which is corroborated in the present study. To highlight the monophyletic group composed by the Bryconinae and Salmininae we expand the previous concept of the Bryconidae to include the Salmininae (Figure 13).

A strongly supported monophyletic group, clade 37, was observed in all our analysis including what we recognize as the family Characidae (Figures 9, 13). The composition of this group is largely comparable to the taxon of that name previously recognized by Malabarba and Weitzman [19] and is characterized morphologically by the lack of a supraorbital bone in its members, a synapomorphy of the Characidae as per this definition (Figure 2a, character 2). The sole difference between the Characidae of this study and that of Malabarba and Weitzman [19] is that under our results the Iguanodectinae is more closely related to Bryconops than it is to the taxa herein assigned to the Characidae (see discussion above).

An additional morphological character potentially supporting the hypothesis of the monophyly of clade 37 is the emergence of the hyoid artery from the anterior ceratohyal proximate to the articulation of that bone with 
the posterior ceratohyal. This feature noted by Castro [69], was more recently used by Mirande ([23]; character 178 ) as a synapomorphy of his node 204 which in that phylogeny included all characiforms without a supraorbital bone.

In all analyses Spintherobolus (clade 50) appears as sister group of all remaining characids in clade 37 (Figure 9). Three of the four recognized species of Spintherobolus were sequenced, excluding the type species (S. papilliferus). This result indicates that the subfamily Cheirodontinae as now defined [70] is not monophyletic in that the remaining members of the subfamily do not resolve as the sister group of Spintherobolus in this analysis. Recent investigations of the monophyly of the Cheirodontinae and the placement of the Spintherobolus involved only a subset of the members of the subfamily $[22,23,33,71]$ and the results herein indicate that the question should be reinvestigated utilizing more complete intrasubfamilial representation.

The remaining species of the Characidae are included in three clades, each with large numbers of species: clade 52 (Figure 10), clade 54 (Figure 11), and clade 55 (Figure 12) in the Bayesian and ML analyses. Interestingly these three same clades, named clades $\mathrm{C}, \mathrm{B}$, and A, respectively, were found in the molecular phylogeny of Javonillo et al. [33] using sequences of some different genes. Clades 54 and 55 (Figure 9) also form a monophyletic group, as proposed by Javonillo et al. [33]. Clade 55 was recognized by Mirande [22,23] as a broad Stevardiinae which is partially in agreement with our results and this name was here applied to clade A. In light of the still evolving state of knowledge of many genera and species in the Characidae we prefer to not formally name the clades $\mathrm{B}$, and $\mathrm{C}$ as proposed by Javonillo et al. [33].

Clade 52 (Figure 10) is equivalent to clade $\mathrm{C}$ of Javonillo et al. [33]. This is the most species-rich group within the Characiformes with more than 500 species [72]. This clade encompasses the speciose genera Astyanax, Hemigrammus, Hyphessobrycon, and Jupiaba, all of which are polyphyletic according to the results of this study and Moenkhausia which was previously demonstrated to be polyphyletic by Mirande [23] and Javonillo et al. [33]. Although we found several strongly supported groups discussed below, some basal nodes could not be resolved. Several groups with overall similar morphology and body shape were well supported, such as the group composed by Hollandichthys, Rachoviscus and Bario and the group consisting of Ctenobrycon plus Psellogrammus. An interesting and well supported group was formed by Stygichthys typhlops, a cave fish [73], and Coptobrycon bilineatus, as sister group of Probolodus heterostomus, Deuterodon iguape and Myxiops aphos. All of these species inhabit very ancient land formations in the northeastern and southeastern regions of Brazil, which are also the areas of residence of primitive lineages in other groups of fishes such as the Trichomycteridae [74] and Loricariidae [75].

Clade 52 has the four genera of Stethaprioninae as a monophyletic group, thereby corroborating the hypothesis advanced by Reis [12] based on morphological evidence. Reis [12] found that Brachychalcinus and Stethaprion are sister-groups to each other, Orthospinus is sister to that clade, and Poptella is the most basal genus in the group. The phylogenetic relationships found herein (Figure 10) differ from that hypothesis. We also found Gymnocorymbus ternetzi to be the sister group of the Stethaprioninae as proposed by Mirande $[22,23]$. The Rhoadsiinae, represented in our study only by Carlana eigenmanni, also falls within clade 52 and is hypothesized to be closely related to Nematobrycon palmeri (Figure 10), a result at variance with the hypothesis of Mirande [22,23].

The second of the large clades in the Characidae is clade 54 (Figure 11). A similar monophyletic group but represented by a smaller number of taxa was observed in the study by Javonillo et al. [33] and named clade B by those authors. This group is composed by two main lineages (clades 69 and 70). Within clade 69, clade 71 includes two genera, Exodon and Roeboexodon, now considered incertae sedis in the Characidae, as a monophyletic group that is sister to all remaining taxa in the clade. These species share a number of distinctive external features, most prominent among these being the mammiliform teeth external to the upper jaw. Exodon and Roeboexodon were grouped with Bryconexodon (not analyzed herein) in a monophyletic clade by Mirande [22] who hypothesized that the group was closely related to the Characinae. In contrast, our study has this group related to a larger clade composed of the Tetragonopterinae, Microschemobrycon casiquiare, and the Characinae (clade 72, Figure 11). A relationship of Exodon with the Tetragonopterinae and Characinae was also proposed by Javonillo et al. [33].

One of the interesting results in our study was the sister group relationship between Microschemobrycon casiquiare and the Characinae (clade 74, Figure 11). Mirande [22,23] found Microschemobrycon to be closely related to the other genera in his Aphyoditeinae, a group which had a composition similar to that initially proposed by Géry [63]. The Characinae in our results is similar to the group of that name as defined by Mirande $[22,23]$ but as noted above, excluding Exodon and Roeboexodon. The Characinae of our study differs from that proposed by Lucena and Menezes [58] by the exclusion of Gnathocharax, Hoplocharax and Heterocharax (see discussion above). In our results, the two analyzed species of Cynopotamus, C. kincaidi and C. venezuelae do 
not form a monophyletic group thereby raising questions as to the monophyly of the genus. The Tetragonopterinae, restricted to the genus Tetragonopterus by Reis [76] is monophyletic and the sister group of the Characinae plus Microschemobrycon. Our data refutes the hypothesis of Mirande [23] who proposed a large Tetragonopterinae, including several genera which are not related to Tetragonopterus in the present study.

The second large group included in clade B is clade 70 (Figure 11) that is composed by the Aphyocharacinae and several genera currently considered incertae sedis in the Characidae. This group has a composition similar to that of the Aphyocharacinae plus Paragoniatinae of Géry [63] which was grouped by Mirande [22] in his redefined Aphyocharacinae (a subfamily that also includes Inpaichthys and Rachoviscus - not sampled in that study). The inclusion of Rachoviscus in the Aphyocharacinae was previously refuted by Thomaz et al. [77]. In our study, Inpaichthys and Rachoviscus belong to clade 52 (Figure 10) while Aphyocharacidium bolivianum appears as the sister group of all members of clade 76 . Mirande [22,23], alternatively, suggested that Aphyocharacidium be included in his Aphyoditeinae. Relationships among these genera in our results differ notably from those proposed by Mirande [22]. In our results, the Aphyocharacinae appears as the sister group of Prionobrama and this group is, in turn, the sister group of the clade composed by Paragoniates, Phenagoniates, Xenagoniates and Leptagoniates. These last four genera share a very characteristic morphology with a very compressed, elongate body and a long anal fin [63].

The third large group in clade 54 is the subfamily Cheirodontinae (clade 77, Figure 11). As discussed above, however, the position of Spintherobolus at the base of the Characidae renders the Cheirodontinae sensu Malabarba [70] paraphyletic. The monophyly of the Cheirodontinae was previously supported by Calcagnotto et al. [32], Mirande [22] and Javonillo et al. [33] but without the analysis of a significant number of genera and species, most notably Spintherobolus. The division of the Cheirodontinae into the tribes Compsurini and Cheirodontini [14] was also not supported by the results of our analysis. Notably, we found that the transAndean cheirodontin species, Nanocheirodon insignis and Pseudocheirodon arnoldi, are the sister group of genera and species occurring in the cis-Andean region. This suggests a very old origin for this clade and more inclusive clades, predating the uplift of the northern Andean cordilleras.

Clade 55 (Figure 12) partially corresponds to clade A of Malabarba and Weitzman [19] who noted the similarity in composition of their clade A to a group proposed by Géry [63]. The monophyly of this clade was corroborated in the taxonomically broad study of Weitzman et al. [20] and Menezes and Weitzman [21], and in the analyses of Calcagnotto et al. [32] and Javonillo et al. [33], albeit based on a fewer number of analyzed taxa in these latter studies. Inside this group, we found a monophyletic Glandulocaudinae, sensu Menezes and Weitzman [21] (clade 84, Figure 12) in which Glandulocauda appears as the sister group of Lophiobrycon and with the clade formed by those taxa as the sister group of Mimagoniates. This is the first real test of the hypothesis of the monophyly of the Glandulocaudinae as delimited in recent studies, since only Mimagoniates was analyzed in previous studies [22,32,33]. This hypothesis differs from that of Castro et al. [78] and Menezes and Weitzman [21] who found Glandulocauda to be the sister group of Mimagoniates and the clade consisting of those taxa as the sister group of Lophiobrycon. An analysis incorporating additional species of Glandulocauda and particularly Mimagoniates is necessary to thoroughly investigate the relationships among these genera.

The second previous recognized characid subfamily found in clade 55 is the Stevardiinae, sensu Weitzman et al. [20]. Although only six of the seventeen recognized genera of the Stevardiinae were included in this study, the results indicate that this subfamily, as proposed by Weitzman et al. [20], is polyphyletic (Figure 12). Gephyrocharax and Corynopoma (tribe Corynopomini) are the sister group of Pseudocorynopoma (tribe Hysteronotini) with this group the sister group of the Glandulocaudinae. Xenurobrycon and Tyttocharax (tribe Xenurobryconini), appear as more basal clades within clade 79 while Planaltina (tribe Diapomini) appears as more derived but not closely related to the remaining analyzed species of the Stevardiinae, sensu Weitzman et al. [20].

The most basal group within clade 55 is composed of Markiana nigripinnis and Bryconamericus emperador (clade 78, Figure 12). The inclusion of M. nigripinnis within clade A is a novel hypothesis. Although this species has ii+9 dorsal-fin rays, the plesiomorphic condition according Malabarba and Weitzman [19], other morphological characteristics including spermatozoa ultrastructure which is very similar to those of the noninseminating members of clade 55 , the presence of only four teeth in the inner premaxillary tooth row, and a short triangular ectopterygoid which is never more than twice the length of the palatine [79] corroborate the hypothesis that $M$. nigripinnis belongs to clade 55 . Mirande $[22,23]$ did not find Markiana to be a member of clade A, but did propose a sister group relationship between M. nigripinnis and Bryconamericus scleroparius. Although only two species of Bryconamericus were included in the present study, the genus appears as polyphyletic since $B$. exodon, the type species of the 
genus, is hypothesized to be more closely related to Odontostoechus and Hypobrycon than to its nominal congener (Figure 12). A polyphyletic Bryconamericus was also obtained in the analyses by Mirande [22,23] and Javonillo et al. [33]; results emphasizing the need for a reappraisal of the limits of the genus. A monophyletic clade composed by Odontostoechus, Hypobrycon and some species of Bryconamericus and Cyanocharax was proposed by Javonillo et al. [33] and parallels the results of this study. The sister group of these genera in our analysis is the clade composed by Piabina argentea and Piabarchus analis. Our study is the first one to investigate the relationships of Piabarchus and this conclusion runs counter to the hypothesis of a sister group relationship between Piabina and Creagrutus proposed by Vari and Harold [18] and Mirande [22,23] based on morphological characters, but not that arrived at by Javonillo et al. [33] in their molecular analysis. A final monophyletic lineage within clade 55 is composed of Knodus meridae (the type species of the genus), Bryconadenos tanaothoros, and Ceratobranchia cf. delotaenia (Figure 12). A sister group relationship between Knodus and Bryconadenos was previously suggested by Weitzman et al. [20] and corroborated by Javonillo et al. [33]. Leaving aside differences in the included species, Mirande's [22] concept of the Stevardiinae is equivalent to clade 55 of this study other than for the addition of Markiana nigripinnis. As discussed previously the concept of the Stevardiinae proposed by Weitzman et al. [20] differs significantly from our results. We consequently recognize clade 55 as the Stevardiinae in the sense of Mirande [22] expanded to include Markiana nigripinnis.

\section{Conclusions}

The definition of the Characidae (our clade 37) as proposed herein (Figure 13) is the most significant contribution of the present study, with both molecular $(B=1$, $\mathrm{ML}=100, \mathrm{MP}=92$ ) and morphological evidence (lack of a supraorbital bone and emergence of the hyoid artery from the posterior portion of the anterior ceratohyal) supporting the recognition of a proposed monophyletic group encompassing approximately one-half of all Recent characiforms.

As noted in the introductory comments, the Characiformes in general and within that order, the Characidae in particular, are speciose assemblages encompassing a number of very distinctive taxa. The results of the present analysis of a large number of species including on the one hand representatives of all of the main lineages of the Characiformes and on the other a large dataset including genes with slow to moderate evolutionary rates provided insight into the phylogenetic relationships of a number of previously problematic taxa. Most notable among these were various genera previously placed as incertae sedis within the Characidae. These results demonstrate that this combination of large numbers of taxa and large datasets should be a productive method for future investigations of phylogenetic relationships among large groups such as the Characiformes. Such future analysis both within the Characiformes and in other groups will presumably provide insight as to the degree to which differences in results between studies with varying degree of taxonomic inclusiveness are a function of the absence of critical taxa versus inadequate datasets resulting in poor degrees of phylogenetic resolution. Notwithstanding the fact that the present study was based on multiple genes and the largest number of species to date in a molecular analysis of the Characiformes, future studies including additional genera and particularly species of species-rich genera are necessary to resolve the questions noted in the discussion and to further improve our understanding of phylogenetic relationships across the Characiformes.

\section{Additional material}

Additional file 1: Specimens used in the phylogenetic analysis.

Additional file 2: Sequences of primers used in present study.

Additional file 3: Species analyzed, collection number, specimen number, and GenBank accession numbers.

\section{Acknowledgements}

We thank all the individuals and institutions who assisted us in the collection and identification of the specimens that served as the basis for this study, with special thanks to Mauro Nirchio, Universidad de Oriente, for the donation of tissue samples from Venezuela, Oris Sanjur, Smithsonian Tropical Research Institute, for the donation of tissue samples from Panama, Martha Valdez-Moreno, El Colegio de la Frontera Sur, for the donation of tissue samples from Mexico, Hernán Ortega, Museo de Historia Natural, Universidad Nacional Mayor de San Marcos, for the donation of tissue samples from Peru, the American Museum of Natural History for the donation of tissue samples of some Cheirodontinae, and Osvaldo T. Oyakawa, Janice Cunha, Caroline Doria, Riviane Garcez, and Gislene TorrenteVilara for the donation of tissue samples from several regions within Brazil. We also thank Markus Alexandrou for his help with the Bayesian analyses. The manuscript was substantially improved with the help of the Associated Editor of BMC and three anonymous reviewers. This study is part of the FAPESP (Fundação de Apoio à Pesquisa do Estado de São Paulo) Thematic Project "Phylogenetic relationships in the Characidae (Ostariophysi: Characiformes) (FAPESP grant number 04/09219-6, R.M.C. Castro, Principal Investigator). The first and eighth authors are CNPq (Conselho Nacional de Desenvolvimento Científico e Tecnológico do Brasil) researchers (CNPq grants numbers 309632/2007-2, 303854/2009-0, respectively). The second, third, fourth and fifth authors were supported by FAPESP (06/05744-4, 06/ 06749-0, 06/04551-8, 06/00545-3, respectively). A Research Coordination Network (RCN) grant from the U.S. National Science Foundation (DEB$0443470, \mathrm{PI}=\mathrm{G}$. Ortí) provided funding for a student exchange program supporting the fourth author.

\section{Author details}

${ }^{1}$ Dept. Morfologia, Instituto de Biociências, Universidade Estadual Paulista, Botucatu, São Paulo, Brazil. ²Dept. Biological Sciences, The George 
Washington University, USA. ${ }^{3}$ Dept. Vertebrate Zoology, Smithsonian Institution, National Museum of Natural History, USA. ${ }^{4}$ Laboratório de Ictiologia de Ribeirão Preto (LIRP), Dept. Biologia, FFCLRP, Universidade de São Paulo, Ribeirão Preto, São Paulo, Brazil.

\section{Authors' contributions}

CO, RMCC participated equally in the design of the study. GSA, KTA and TCM did most of the laboratory experiments. CO, GSA, KTA, TCM and GO analyzed parts of the data and did phylogenetic analyses. All authors discussed results. CO, GO and RPV wrote substantial parts of the manuscript. All authors read and approved the final manuscript.

Received: 25 January 2011 Accepted: 26 September 2011 Published: 26 September 2011

\section{References}

1. Nelson JS: Fishes of the World. 4 edition. New York: John Wiley \& Sons Inc: 2006.

2. Weitzman SH, Vari RP: Miniaturization in South American freshwater fishes; and overview and discussion. Proc Biol Soc Wash 1988, 101:444-465.

3. Flecker AS: Ecosystem engineering by a dominant detritivore in a diverse tropical stream. Ecology 1996, 77:1845-1854

4. Taylor BW, Flecker AS, Hall RO Jr: Disrupts carbon flow in a diverse tropical river. Science 2006, 313:833-836.

5. Zanata AM, Vari RP: The family Alestidae (Ostariophysi, Characiformes): a phylogenetic analysis of a trans-Atlantic clade. Zool J Linn Soc 2005, 145:1-144.

6. Reis RE, Kullander SO, Ferraris CJ Jr: Check List of the Freshwater Fishes of South and Central America (CLOFFSCA) Porto Alegre: Edipucrs; 2003.

7. Ortí G, Sivasundar A, Dietz K, Jégu M: Phylogeny of the Serrasalmidae (Characiformes) based on mitochondrial DNA sequences. Genet Mol Biol 2008, 31(suppl):343-351.

8. Buckup PA: Relationships of the Characidiinae and phylogeny of characiform fishes (Teleostei: Ostariophysi). In Phylogeny and Classification of Neotropical Fishes. Edited by: Malabarba LR, Reis RE, Vari RP, Lucena ZM, Lucena CA. Porto Alegre: Edipucrs; 1998:123-144.

9. Vari RP: Phylogenetic relationships of the families Curimatidae, Prochilodontidae, Anostomidae, and Chilodontidae (Pisces: Characiformes). Smithsonian Contrib Zool 1983, 378:1-60

10. Sidlauskas BL, Vari RP: Phylogenetic relationships within the South American fish family Anostomidae (Teleostei, Ostariophysi, Characiformes). Zool J Linn Soc 2008, 154:70-210.

11. Machado-Allison A: Estudios sobre la sistematica de la subfamília Serralsaminae (Teleostei: Characidae). Parte II. Discussion sobre la condicion monofiletica de la subfamilia. Acta Biol Venez 1983, 11:145-195.

12. Reis RE: Systematic revision of the Neotropical characid subfamily Stethaprioninae (Pisces, Characiformes). Comun Mus Ciênc Tecnol PUCRS Sér Zool 1989, 2:3-86.

13. Lucena CSA, Menezes NA: A phylogenetic analysis of Roestes Günther and Gilbertolus Eigenmann, with a hypothesis on the relationships of the Cynodontidae and Acestrorhynchidae (Teleostei: Ostariophysi: Characiformes). In Phylogeny and Classification of Neotropical Fishes. Edited by: Malabarba LR, Reis RE, Vari RP, Lucena ZMS, Lucena CAS. Porto Alegre: Edipucrs; 1998:261-278

14. Malabarba LR: Monophyly of the Cheirodontinae, characters and major clades. In Phylogeny and Classification of Neotropical Fishes. Edited by: Malabarba LR, Reis RE, Vari RP, Lucena ZMS, Lucena CAS. Porto Alegre: Edipucrs; 1998:193-234

15. Malabarba MCSL: Phylogeny of fossil Characiformes and paleobiogeography of the Tremembé Formation, São Paulo, Brazil. In Phylogeny and Classification of Neotropical Fishes. Edited by: Malabarba LR, Reis RE, Vari RP, Lucena ZMS, Lucena CAS. Porto Alegre: Edipucrs; 1998:69-84.

16. Weitzman SH, Menezes NA: Relationships of the tribes and genera of the Glandulocaudinae (Ostariophysi: Characiformes: Characidae) with a description of a new genus, Chrysobrycon. In Phylogeny and Classification of Neotropical Fishes. Edited by: Malabarba LR, Reis RE, Vari RP, Lucena ZMS, Lucena CAS. Porto Alegre: Edipucrs; 1998:171-192.
17. Toledo-Piza M: The Neotropical fish subfamily Cynodontinae (Teleostei: Ostariophysi: Characiformes): a phylogenetic study and a revision of Cynodon and Rhaphiodon. Am Mus Novitates 2000, 3286.

18. Vari RP, Harold AS: Phylogenetic study of the Neotropical fish genera Creagrutus Günther and Piabina Reinhardt (Teleostei: Ostariophysi: Characiformes), with a revision of the cis-Andean species. Smithsonian Contr Zool 2001, 613:1-239.

19. Malabarba LR, Weitzman SH: Description of a new genus with six species from Southern Brazil, Uruguay and Argentina with discussion of a putative characid clade (Teleostei: Characiformes: Characidae). Comun Mus Ciênc Tecnol PUCRS Sér Zool Porto Alegre 2003, 16:67-151.

20. Weitzman SH, Menezes NA, Evers H-G, Burns JR: Putative relationships among inseminating and externally fertilizing characids, with a description of a new genus and species of Brazilian inseminating fish bearing an anal-fin gland in males (Characiformes: Characidae). Neotrop Ichthyol 2005, 3:329-360.

21. Menezes NA, Weitzman SH: Systematics of the Neotropical subfamily Glandulocaudinae (Teleostei: Characiformes: Characidae). Neotrop Ichthyol 2009, 7:295-370.

22. Mirande JM: Weighted parsimony phylogeny of the family Characidae (Teleostei: Characiformes). Cladistics 2009, 25:1-40

23. Mirande JM: Phylogeny of the family Characidae (Teleostei: Characiformes): from characters to taxonomy. Neotrop Ichthyol 2010 8:385-568

24. Vari RP, Castro RMC, Raredon SJ: The Neotropical fish family Chilodontidae (Teleostei: Characiformes): a phylogenetic study and a revision of Caenotropus Günther. Smithsonian Contrib Zool 1995, 577:1-32

25. Vari RP: Anatomy, relationships and classification of the families Citharinidae and Distichodontidae (Pisces: Characoidei). Bull Brit Mus Nat Hist Zool 1979, 36:261-344

26. Vari RP: A phylogenetic study of the neotropical characiform family Curimatidae (Pisces: Ostariophysi). Smithsonian Contrib Zool 1989, 471:1-71.

27. Langeani F: Phylogenetic study of the Hemiodontidae (Ostariophysi: Characiformes). In Phylogeny and Classification of Neotropical Fishes. Edited by: Malabarba LR, Reis RE, Vari RP, Lucena ZM, Lucena CA. Porto Alegre: Edipucrs; 1998:145-160.

28. Castro RMC, Vari RP: Detritivores of the South American fish family Prochilodontidae (Teleostei: Ostariophysi: Characiformes): a phylogenetic and revisionary study. Smithsonian Contrib Zool 2004, 622:1-189.

29. Lima FCT, Malabarba LR, Buckup PA, da Silva JFP, Vari RP, Harold A, Benine R, Oyakawa OT, Pavanelli CS, Menezes NA, Lucena CAS, Malabarba MCSL, Lucena ZMS, Reis RE, Langeani F, Cassati L, Bertaco VA Moreira C, Lucinda PHF: Genera incertae sedis in Characidae. In Check List of the Freshwater Fishes of South and Central America. Edited by: Reis RE, Kullander SE, Ferraris Jr CJ. Porto Alegre: Edipucrs; 2003:106-169.

30. Ortí $G$, Meyer $A$ : The radiation of characiform fishes and the limits of resolution of mitochondrial ribosomal DNA sequences. Syst Biol 1997, 46:75-100.

31. Ortí $\mathrm{G}$ : Radiation of characiform fishes: evidence from mitochondrial and nuclear DNA sequences. In Molecular Systematics of Fishes. Edited by: Kocher TD, Stepien CA. San Diego: Academic Press; 1997:219-243.

32. Calcagnotto $D$, Schaefer $S A$, DeSalle R: Relationships among characiform fishes inferred from analysis of nuclear and mitochondrial gene sequences. Mol Phylogenet Evol 2005, 36:135-153.

33. Javonillo R, Malabarba LR, Weitzman SH, Burns JR: Relationships among major lineages of characid fishes (Teleostei: Ostariophysi: Characiformes), based on molecular sequence data. Mol Phylogenet Evol 2010, 54:498-511.

34. Buckup PA: Triportheinae. In Catálogo das espécies de peixes de água doce do Brasil. Edited by: Buckup PA, Menezes NA, Ghazzi MS. Rio de Janeiro: Museu Nacional; 2007:43-44.

35. Hall TA: BioEdit: a user-friendly biological sequence alignment editor and analysis program for Windows 95/98/NT. Nucl Acids Symp Ser 1999, 41:95-98.

36. Edgar RC: MUSCLE: multiple sequence alignment with high accuracy and high throughput. Nucleic Acids Res 2004, 32:1792-1797.

37. Stamatakis A, Hoover P, Rougemont J: A rapid bootstrap algorithm for the RAxML web servers. Syst Biol 2008, 57:758-771. 
38. Stamatakis A: RAxML-VI-HPC: Maximum likelihood-based phylogenetic analyses with thousands of taxa and mixed models. Bioinformatics 2006 22:2688-2690

39. Tamura K, Peterson D, Peterson N, Stecher G, Nei M, Kumar S: MEGA5: Molecular Evolutionary Genetics Analysis using Maximum Likelihood, Evolutionary Distance, and Maximum Parsimony Methods. Mol Biol Evol

40. Xia X, Xie Z: DAMBE: Data analysis in molecular biology and evolution. $J$ Heredity 2001, 92:371-373.

41. Xia X, Xie Z, Salemi M, Chen L, Wang Y: An index of substitution saturation and its application. Mol Phylogenet Evol 2003, 26:1-7.

42. Xia X, Lemey P: Assessing substitution saturation with DAMBE. In The Phylogenetic Handbook: A Practical Approach to DNA and Protein Phylogeny. Volume 2009.. 2 edition. Edited by: Lemey P, Salemi M, Vandamme A-M. Cambridge: University Press; 615-630.

43. Baker A, Yu X, DeSalle R: Assessing the relative contribution of molecular and morphological characters in simultaneous analysis trees. Mol Phylogenet Evol 1998, 9:427-436.

44. Baker R, DeSalle R: Multiple sources of character information and the phylogeny of Hawaiian drosophilids. Syst Biol 1997, 46:654-673.

45. Sorenson MD, Franzosa EA: TreeRot, version 3. Boston University, Boston, MA; 2007.

46. Swofford DL: PAUP*: Phylogenetic analysis using parsimony (*and other methods). Version 4. Massachusetts: Sinauer Associates; 2003.

47. Felsenstein J: Confidence limits on phylogenies: an approach using the bootstrap. Evolution 1985, 39:783-791.

48. Ronquist F, Huelsenbeck JP: MrBayes 3: Bayesian phylogenetic inference under mixed models. Bioinformatics 2003, 19:1572-1574.

49. Li C, Ortí G, Zhang G, Lu G: A practical approach to phylogenomics: The phylogeny of ray-finned fish (Actinopterygii) as a case study. BMC Evol Biol 2007, 7:44.

50. Posada D, Crandall KA: Modeltest: testing the model of DNA substitution. Bioinformatics 1998, 14:817-818.

51. Posada D, Buckley TR: Model selection and model averaging in phylogenetics: Advantages of Akaike Information Criterion and Bayesian approaches over likelihood ratio tests. Syst Biol 2004, 53:793-808.

52. Li C, Lu G, Ortí G: Optimal data partitioning and a test case for ray-finned fishes (Actinopterygii) based on ten nuclear loci. Syst Biol 2008, 57:519-539.

53. McGuire JA, Witt CC, Altshuler DL, Remsen JV Jr: Phylogenetic systematics and biogeography of hummingbirds: Bayesian and maximum likelihood analyses of partitioned data and selection of an appropriate partitioning strategy. Syst Biol 2007, 56:837-856

54. Rambaut A, Drummond AJ: Tracer v1 42004 [http://beast.bio.ed.ac.uk/ Tracer].

55. Jobb G: TREEFINDER. Version of October 2008. Munich, Germany. Distributed by the author at http://www.treefinder.de.

56. Shimodaira H, Hasegawa M: Multiple comparisons of log-likelihoods with applications to phylogenetic inference. Mol Biol Evol 1999, 16:1114-1116.

57. Shimodaira $\mathrm{H}$ : An approximately unbiased test of phylogenetic tree selection. Syst Biol 2002, 51:492-508.

58. Lucena CAS, Menezes NA: Subfamily Characinae. In Check List of the Freshwater Fishes of South and Central America. Edited by: Reis RE, Kullander SE, Ferraris Jr CJ. Porto Alegre: Edipucrs; 2003:200-208.

59. Fink SV, Fink WL: Interrelationships of ostariophysan fishes (Teleostei). In Interrelationships of fishes. Edited by: Stiassny MLJ, Parenti LR, Johnson GD San Diego: Academic Press; 1996:209-249.

60. Vari RP: Higher level phylogenetic concepts within characiforms (Ostariophysi), a historical review. In Phylogeny and Classification of Neotropical Fishes. Edited by: Malabarba LR, Reis RE, Vari RP, Lucena ZMS, Lucena CAS. Porto Alegre: Edipucrs; 1998:111-122.

61. Arroyave J, Stiassny MLJ: Phylogenetic relationships and the temporal context for the diversification of African characins of the family Alestidae (Ostariophysi: Characiformes): Evidence from DNA sequence data. Mol Phylogenet Evol .

62. Vari RP: The neotropical fish family Ctenoluciidae (Teleostei: Ostariophysi: Characiformes): supra and intrafamilial phylogenetic relationships, with a revisionary study. Smithsonian Contrib Zool 1995, 564:1-97.

63. Géry J: Characoids of the World Neptune City: TFH Publications; 1977.

64. Albert JS, Bart HL Jr, Reis RR: Species richness and cladal diversity. In Historical Biogeography of Neotropical freshwater fishes. Edited by: Albert JS, Reis RE. California: University of California Press; 2011:89-104
65. Lucena CAS: Relações filogenéticas e definição do gênero Roeboides Günther (Ostariophysi: Characiformes: Characidae). Comun Mus Ciênc Tecnol PUCRS, Sér Zool Porto Alegre 1998, 11:19-59.

66. Menezes NA: Family Acestrorhynchidae. In Check List of the Freshwater Fishes of South and Central America. Edited by: Reis RE, Kullander SE, Ferraris Jr CJ. Porto Alegre: Edipucrs; 2003:231-233.

67. Weitzman SH: The osteology and relationships of the South American characoid fishes of the subfamily Gasteropelecinae. Stanford Ichthyol Bull 1954, 4:213-263.

68. Weitzman SH: Further notes on the relationships and classification of the South American characoid fishes of the subfamily Gasteropelecinae. Stanford Ichthyol Bull 1960, 7:217-239.

69. Castro RMC: Osteologia e relações filogenéticas de Engraulisoma taeniatum Castro, 1981 (Ostariophysi, Characiformes, Characidae). Brazil: Universidade de São Paulo; 1984, Unpublished Master dissertation São Paulo.

70. Malabarba LR: Subfamily Cheirodontinae. In Check List of the Freshwater Fishes of South and Central America. Edited by: Reis RE, Kullander SE, Ferraris Jr CJ. Porto Alegre: Edipucrs; 2003:215-221.

71. Bührnheim CM, Carvalho TP, Malabarba LR, Weitzman SH: A new genus and species of characid fish from the Amazon basin - the recognition of a relictual lineage of characid fishes (Ostariophysi: Cheirodontinae: Cheirodontini). Neotrop Ichthyol 2008, 6:663-678.

72. Eschmeyer WN, Fong JD: Species of fishes by family/subfamily. 2010 [http://research.calacademy.org/research/ichthyology/catalog/ SpeciesByFamily.asp].

73. Moreira CR, Bichuette ME, Oyakawa OT, de Pinna MCC, Trajano E: Rediscovery and redescription of the unusual subterranean characiform Stygichthys typhlops, with notes on its life history. J Fish Biol 2010, 76:1815-1824.

74. de Pinna MC: Phylogenetic relationships of Neotropical Siluriformes (Teleostei: Ostariophysi): historical overview and synthesis of hypotheses. In Phylogeny and Classification of Neotropical Fishes. Edited by: Malabarba LR, Reis RE, Vari RP, Lucena ZM, Lucena CA. Porto Alegre: Edipucrs; 1998:279-330

75. Armbruster JW: Phylogenetic relationships of the suckermouth armoured catfishes (Loricariidae) with emphasis on the Hypostominae and the Ancistrinae. Zool J Linn Soc 2004, 141:1-80.

76. Reis RE: Subfamily Tetragonopterinae. In Check List of the Freshwater Fishes of South and Central America. Edited by: Reis RE, Kullander SE, Ferraris Jr CJ. Porto Alegre: Edipucrs; 2003:209-211.

77. Thomaz AT, Malabarba LR, Bonatto SL: The phylogenetic placement of Hollandichthys Eigenmann 1909 (Teleostei: Characidae) and related genera. Mol Phylogenet Evol 2010, 57:1347-1352.

78. Castro RMC, Ribeiro AC, Benine RC, Melo ALA: Lophiobrycon weitzmani, a new genus and species of glandulocaudine fish (Characiformes: Characidae) from the rio Grande drainage, upper rio Paraná system, southeastern Brazil. Neotrop Ichthyol 2003, 1:11-19.

79. Baicere-Silva CM, Benine RC, Quagio-Grassiotto I: Markiana nigripinnis (Perugia, 1891) as a putative member of the subfamily Stevardiinae (Characiformes: Characidae): spermatic evidence. Neotrop Ichthyol 2011, 9:371-376

doi:10.1186/1471-2148-11-275

Cite this article as: Oliveira et al:: Phylogenetic relationships within the speciose family Characidae (Teleostei: Ostariophysi: Characiformes) based on multilocus analysis and extensive ingroup sampling. BMC Evolutionary Biology 2011 11:275. 